\title{
Integration of anaerobic digestion with thermal gasification and pressurized solid oxide electrolysis cells for high efficiency bio-SNG production
}

\author{
Clausen, Lasse Røngaard; Butera, Giacomo; Jensen, Søren Højgaard
}

Published in:

Energy

Link to article, DOI:

10.1016/j.energy.2019.116018

Publication date:

2019

Document Version

Peer reviewed version

Link back to DTU Orbit

Citation (APA):

Clausen, L. R., Butera, G., \& Jensen, S. H. (2019). Integration of anaerobic digestion with thermal gasification and pressurized solid oxide electrolysis cells for high efficiency bio-SNG production. Energy, 188, [116018]. https://doi.org/10.1016/j.energy.2019.116018

\section{General rights}

Copyright and moral rights for the publications made accessible in the public portal are retained by the authors and/or other copyright owners and it is a condition of accessing publications that users recognise and abide by the legal requirements associated with these rights.

- Users may download and print one copy of any publication from the public portal for the purpose of private study or research.

- You may not further distribute the material or use it for any profit-making activity or commercial gain

- You may freely distribute the URL identifying the publication in the public portal 


\title{
Integration of anaerobic digestion with thermal gasification and pressurized solid oxide electrolysis cells for high efficiency bio-SNG production
}

\author{
Lasse R. Clausen ${ }^{1, *}$, Giacomo Butera ${ }^{1}$, Søren Højgaard Jensen ${ }^{2}$ \\ ${ }^{1}$ Section of Thermal Energy, Department of Mechanical Engineering, Technical University of Denmark (DTU), Nils \\ Koppels Allé Bld. 403, 2800 Kgs. Lyngby, Denmark \\ ${ }^{2}$ Department of Energy Technology, Aalborg University, Fredrik Bajers Vej 5, 9100 Aalborg, Denmark
}

Received: $\mathbf{x x}$

\begin{abstract}
The integration of anaerobic digestion and thermal gasification can ensure a high biomass utilization, as the unconverted biomass from digesters can be converted by thermal gasification. When integrating steam electrolysis or co-electrolysis, all the $\mathrm{CO}$ and $\mathrm{CO}_{2}$ in the biogas and gasification gas can be upgraded to synthetic natural gas (SNG), achieving a very high bio-SNG yield per biomass input. In this paper, a highly integrated system combining anaerobic digestion, thermal gasification, and pressurized solid oxide cells for bio-SNG production from manure is presented and analyzed by thermodynamic modeling. The system is compared to a similar system without anaerobic digestion. The analysis finds that the energy yield of bio-SNG can reach $138 \%$ in relation to the manure input (LHV-dry), while the yield drops to $107 \%$ without anaerobic digestion.

The total energy efficiency from manure and electricity to bio-SNG can reach 79\% with anaerobic digestion and $64 \%$ without it. By combining thermal gasification and anaerobic digestion, it is thereby almost possible to reach the same efficiency as a thermal gasification system operating on wood (up to $84 \%)$.
\end{abstract}

Keywords: electrolysis, internal methanation, steam drying, mechanical vapor recompression, synthetic natural gas, thermodynamic analysis.

\section{Introduction}

Conversion of wet biomass, such as manure and sludge, is usually done by anaerobic digestion for biogas production. A common issue with anaerobic digestion is the amount of unconverted biomass leaving the biogas digester as digestate. The biomass conversion varies significantly between digesters and feedstocks, but typical biogas plants convert $50-60 \%$ of the organic matter or volatile solids (VS) in the incoming biomass [1] $]^{1}$. In the case of manure utilization, the digestate is typically spread on agricultural land as fertilizer, which is environmentally much better than spreading raw manure. However, a significant amount of the carbon in the digestate is converted to $\mathrm{CO}_{2}$ and escapes to the atmosphere $[1]^{2}$. From an environmental perspective, as well as an energy perspective, it could make sense to further process the digestate before returning the nutrients in the digestate to agriculture. Thermal gasification would be able to convert the digestate to gas and nutrient-rich ash or biochar. Experimental studies have shown that gasification ash or biochar can be suitable fertilizers for agriculture $[2,3]$. The gas produced by gasification can be upgraded together with biogas to biomethane,

\footnotetext{
${ }^{1}$ For pig manure, the VS conversion is measured to be $46 \%$ [1]. The measured value was compared with values obtained in other studies, showing that the VS conversion of pig manure can be $47-78 \%$ [1].

${ }^{2}$ See supporting information of ref [1]. After 332 hours of incubation, $30-35 \%$ of the carbon in the digestate was converted to $\mathrm{CO}_{2}$.
} 
also called bio-SNG (synthetic natural gas), and injected into the natural gas grid. Energy-efficient and effective dewatering and drying of the digestate is necessary to make an overall feasible digestate utilization system. Steam drying represents a good choice, as it can use waste heat from the catalytic methanation process as well as supply steam for gasification and steam electrolysis. Excess steam from the steam dryer can also be used for mechanical vapor recompression (MVR) if too little waste heat is available downstream. By integrating steam electrolysis or co-electrolysis with a catalytic methanation reactor, all the $\mathrm{CO}$ and $\mathrm{CO}_{2}$ in the gasification gas, as well as the $\mathrm{CO}_{2}$ in the biogas, can be upgraded to methane $\left(\mathrm{CH}_{4}\right)$. Thereby fully utilizing the biomass carbon input and avoiding plant $\mathrm{CO}_{2}$ emissions. The advantage of co-electrolysis using solid oxide electrolysis cells (SOEC) is that, at pressurized conditions, a part of the methane synthesis can occur in the electrolysis cell. This increases energy efficiency because the heat from the exothermic methane synthesis can directly replace some of the electricity input to the electrolyzer [4,5]. The overall system analyzed in this paper is shown in Fig. 1.

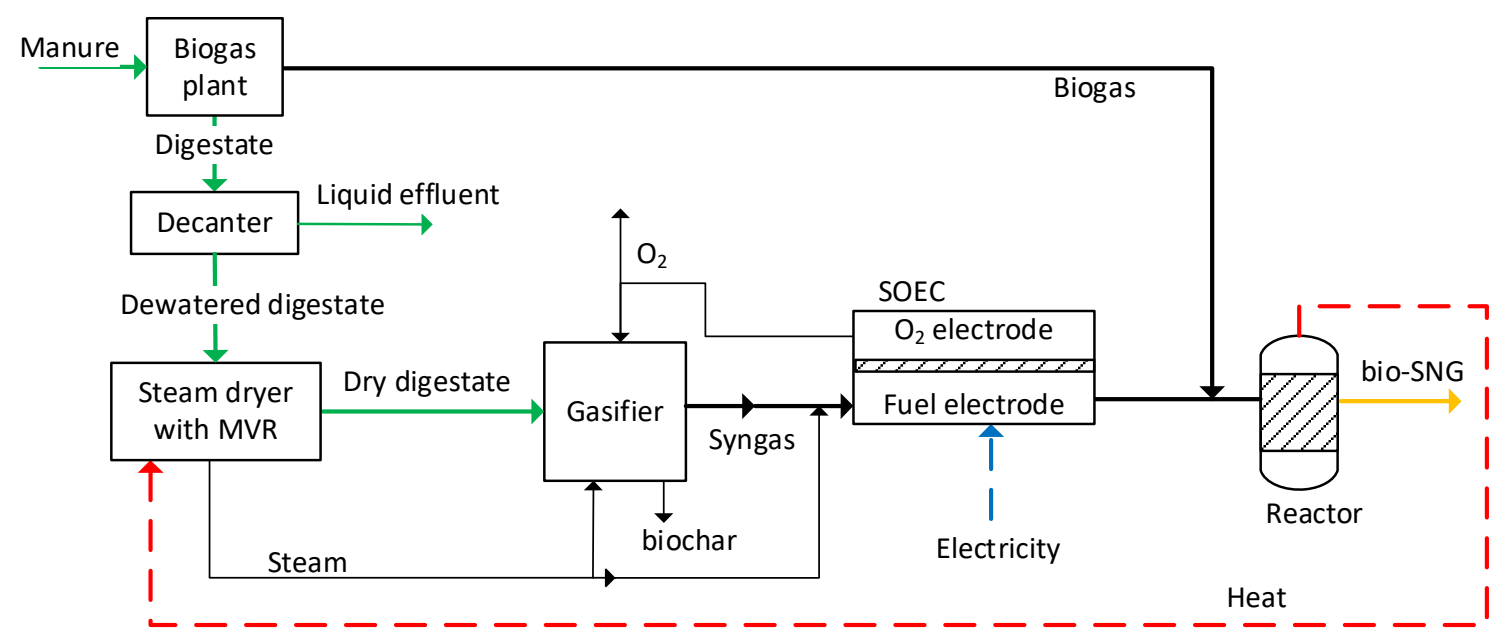

Fig. 1. Simplified flowsheet of the manure to bio-SNG conversion system.

The system is compared with a similar one without a biogas digester (Fig. 2) that could be more suited for large-scale implementations, as the manure could be dewatered at the farm and then transported over longer distances without making the system economically or environmentally unfeasible.

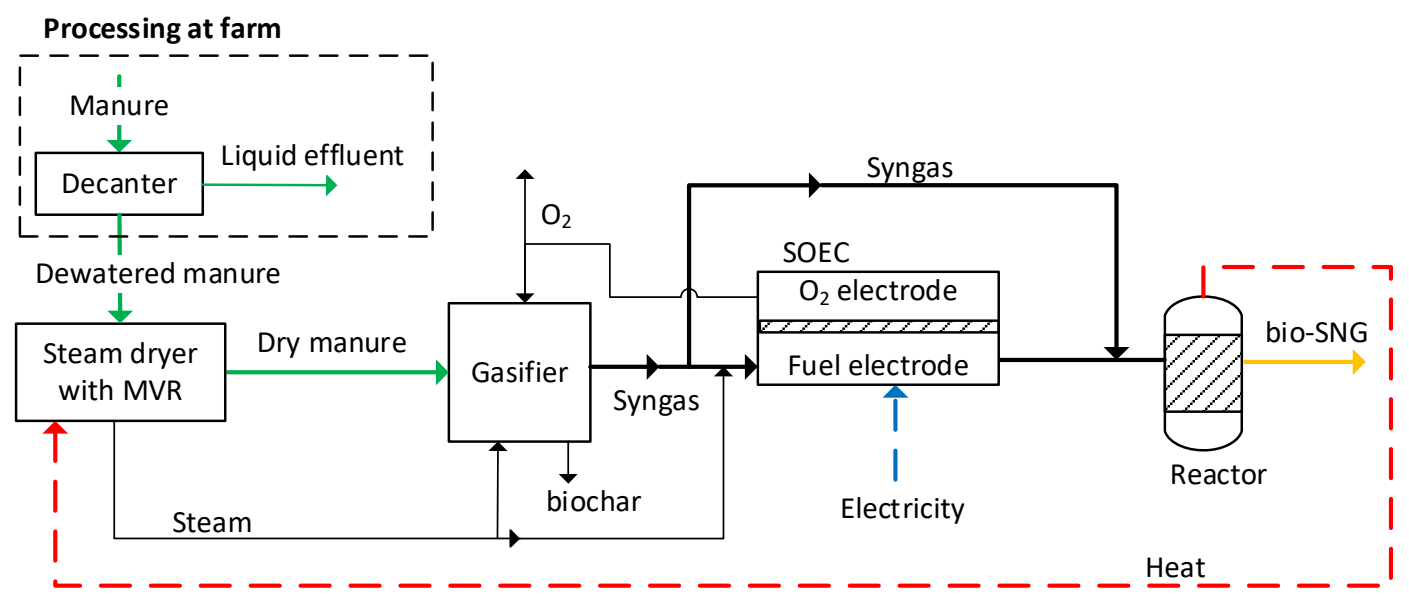

Fig. 2. Simplified flowsheet of the large-scale manure to bio-SNG conversion system with dewatering at a farm and without a biogas plant. 
This study builds directly upon two previous papers published by the authors. In the first paper [6], thermochemical conversion of wet biomass, such as manure and sludge, was analyzed and the results showed that by combining gasification with steam drying and steam electrolysis, it is possible to convert mechanically dewatered biomass (70 wt\% water) without sacrificing system energy efficiency. The efficiency of the conversion of electricity and biomass to bio-SNG was calculated to be $70 \%$ (LHV-dry). In the current paper, it is shown that this efficiency can be further increased using pressurized coelectrolysis and MVR in combination with the steam dryer. In the second paper [7], wood was used on a system similar to the one shown in Fig. 2 but without the steam dryer and decanter. The efficiency of the conversion of electricity and dry wood to bio-SNG was calculated to be $84 \%$ (LHV-dry). This system is a modified version of the electricity storage system presented by Butera et al. [5]. In that system, the electricity was stored as SNG and then converted back to electricity when needed, with a storage efficiency of up to $80 \%$ [5]. The combination of anaerobic digestion and thermal gasification has been investigated before: 1 ) Li et al. tested a high-solid anaerobic digestion (HSAD) combined with thermal gasification to increase the gas yield. The effect on gas LHV from the gasifier was examined when mixing digestate with wood chips before the gasifier [8]; 2) Dussan et al. investigated the utilization of waste water sludge produced by anaerobic digestion and thermal gasification for power generation [9]; 3) Wall et al. proposed two cascading energy systems on an overall conceptual level, combining anaerobic digestion and thermal gasification for bio-SNG production. In one of the energy systems, water electrolysis was incorporated to boost methane production [10]. Furthermore, a review from 2019 about the coupling of anaerobic digestion with either gasification, pyrolysis or hydrothermal carbonization emphasized the importance of energy efficient drying of digestate before gasification or pyrolysis, and also the issue of ash agglomeration in the gasifier was highlighted, as digestate has a high ash content [11]. Moreover, other studies combined thermal gasification and electrolysis for the production of biofuels such as bio-SNG [12,13], methanol [14], and dimethyl ether (DME) [15]. Four of these five studies used steam electrolysis for hydrogen production, which is then mixed with the gasification syngas before fuel synthesis, whereas the other study used co-electrolysis directly on the cleaned gasification syngas [15]. Co-electrolysis was performed at atmospheric pressure to avoid methane synthesis inside the SOEC, as the syngas was used for DME synthesis. The main objective of the current paper is to show that even wet and ash-rich biomass such as manure and sludge can be converted to bio-SNG with almost the same conversion efficiency as dry woody biomass ( $84 \%$ [7]). Another objective is to highlight the synergies between anaerobic digestion and thermal gasification and to show that the highest conversion efficiencies for manure and sludge are achieved when combing these two technologies.

\section{System design and modeling}

The purpose of the paper is to evaluate a novel manure utilization system combining anaerobic digestion with thermal gasification and pressurized solid oxide cells. An early-stage design modeling approach is therefore adopted, using zero-dimensional component models. The component-based thermodynamic modeling tool DNA is used. DNA is an open-source software developed by DTU Mechanical Engineering $[16,17]$. Process design parameters and key assumptions for the individual components are listed in Table 1, and further modeling details and assumptions are described below for the major system components. First, a step-by-step walkthrough of the system is presented together with a more detailed system flowsheet (Fig. 3). Full-detail system flowsheets are provided in the appendix. 


\subsection{Overall plant description}

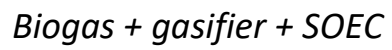

Manure is anaerobically digested in the biogas plant, producing biogas and an effluent digestate. The digestate is mechanically dewatered by a decanter centrifuge, pressurized to 4 bar, and fed to a steam dryer by a screw conveyor system. The dried digestate is converted to syngas by thermal gasification using oxygen from the downstream SOEC and steam from the steam dryer. The syngas is then cooled to condense out water vapor in order to ease sulfur removal, pressurized to the SOEC operating pressure, and cleaned for sulfur by metal oxides before being humidified by hot water injection. Additional water vapor is added as pure steam generated by the downstream cooled methanator. The humid gas is then heated to $\sim 680^{\circ} \mathrm{C}$ by recuperation with hot methane-rich gas from the SOEC operating at $750{ }^{\circ} \mathrm{C}$.

A fraction of the generated oxygen from the SOEC is sent to the gasifier, while the main part is expanded in a turbine before being cooled and vented. The methane-rich gas from the SOEC is mixed with the cleaned and pressurized biogas before being sent to the cooled methanator. The gas from the methanator mainly contains methane and water vapor. The water vapor is removed by condensation, and the generated hot water is used in the upstream humidifier. The dry gas is then pressurized to 20 bar and fed to an adiabatic methanator in order to reach a methane content suited for grid injection.

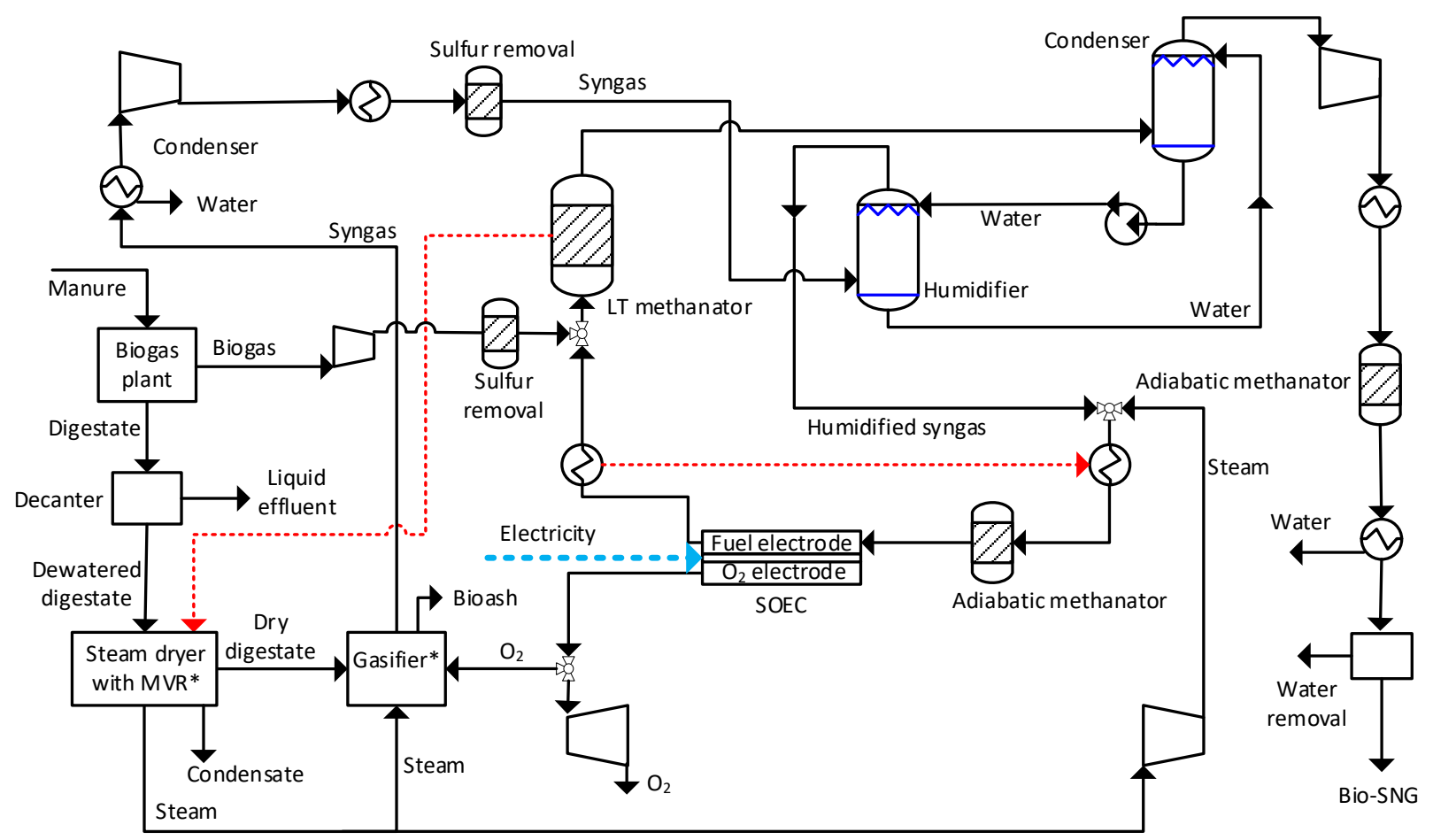

Fig. 3. Flowsheet of the manure to bio-SNG conversion system with all process steps. ${ }^{*}$ Flowsheets of the steam dryer and gasifier can be seen below.

Gasifier + SOEC

The above-described system is compared with a very similar system lacking the biogas plant. The manure is sent directly to the decanter centrifuge, which in this case can be placed decentralized on each farm. The dewatered manure is sent to the steam dryer and then follows the path described above. This system design could be feasible for large-scale plants, while the system with biogas is limited in size due to the cost of transporting raw manure. 


\subsection{Biogas plant}

The biogas plant is modeled based on one of the world's largest biogas plants in operation, which was built in Korskro, Denmark, in 2019. The size of the plant is set to $25 \mathrm{MW}$ of biogas (LHV) based on a production of 22 million $\mathrm{m}^{3}$ per year of upgraded biogas for the gas grid, as stated by the manufacturer's website [18]. The main feedstock for the plant is manure from cows and pigs. The feedstock composition used in the modeling was based on pig manure. It is assumed that the ultimate analysis of the digestate on a dry and ash-free basis is equal to that of the manure [19]. This is also supported by comparing biomass and waste sample data on the Phyllis2 database [20]. The conversion of pig manure in anaerobic digestion varies significantly, an interval of $47-78 \%$ is reported in the literature according to [1], while measurements reported in the same study showed a conversion of $46 \%$ of the organic matter. A conversion of $50-60 \%$ is a reasonable interval, considering that real biogas plants typically co-digest other organic materials. The conversion of organic nitrogen is assumed to follow the conversion of organic matter (50-60\%), and the resulting ammonia $\left(\mathrm{NH}_{3}\right)$ is dissolved in the output digestate. Most of this ammonia leaves the system with the liquid effluent of the decanter. See Table 1 for further design parameters of the biogas plant.

\subsection{Steam dryer}

The steam dryer is modeled based on the commercial steam dryer from EnerDry A/S [21]. It is a pressurized fluid bed-type dryer that is used for drying various wet substances, such as sugar beet pulp, waste water sludge, and wood chips [21]. Screw conveyers are used to feed the wet biomass to the pressurized dryer at 4 bar. A published mass and energy balance from the manufacturer forms the basis of the model (Fig. 4). The drying steam is circulated between the heat exchanger placed in the middle of the dryer and the donut-shaped fluid bed dryer placed around the central heat exchanger (Fig. 4). The heat exchanger is divided into two parts, the lower part heats the dryer steam by the condensation of medium pressure supply steam ( 7-27 bar), while the small upper part preheats the drying steam by cooling the condensate generated by the condensation of the supply steam (Fig. 4). A steam blower placed in the bottom of the dryer ensures the recirculation of drying steam and fluidization of the donut-shaped fluid bed dryer. The size $\mathrm{H}$ dryer shown in Fig. 4 is too large even for the world's biggest biogas plant. On the other hand, the smallest available size (size E) is sufficiently large. The evaporation capacity of the dryer is adjusted by varying the supply steam pressure. The evaporation capacity increases by a factor of $\sim 3.5-4.5$ when raising the supply steam pressure from the minimum value of $\sim 7$ bar to the maximum value of $\sim 27$ bar [21]. 


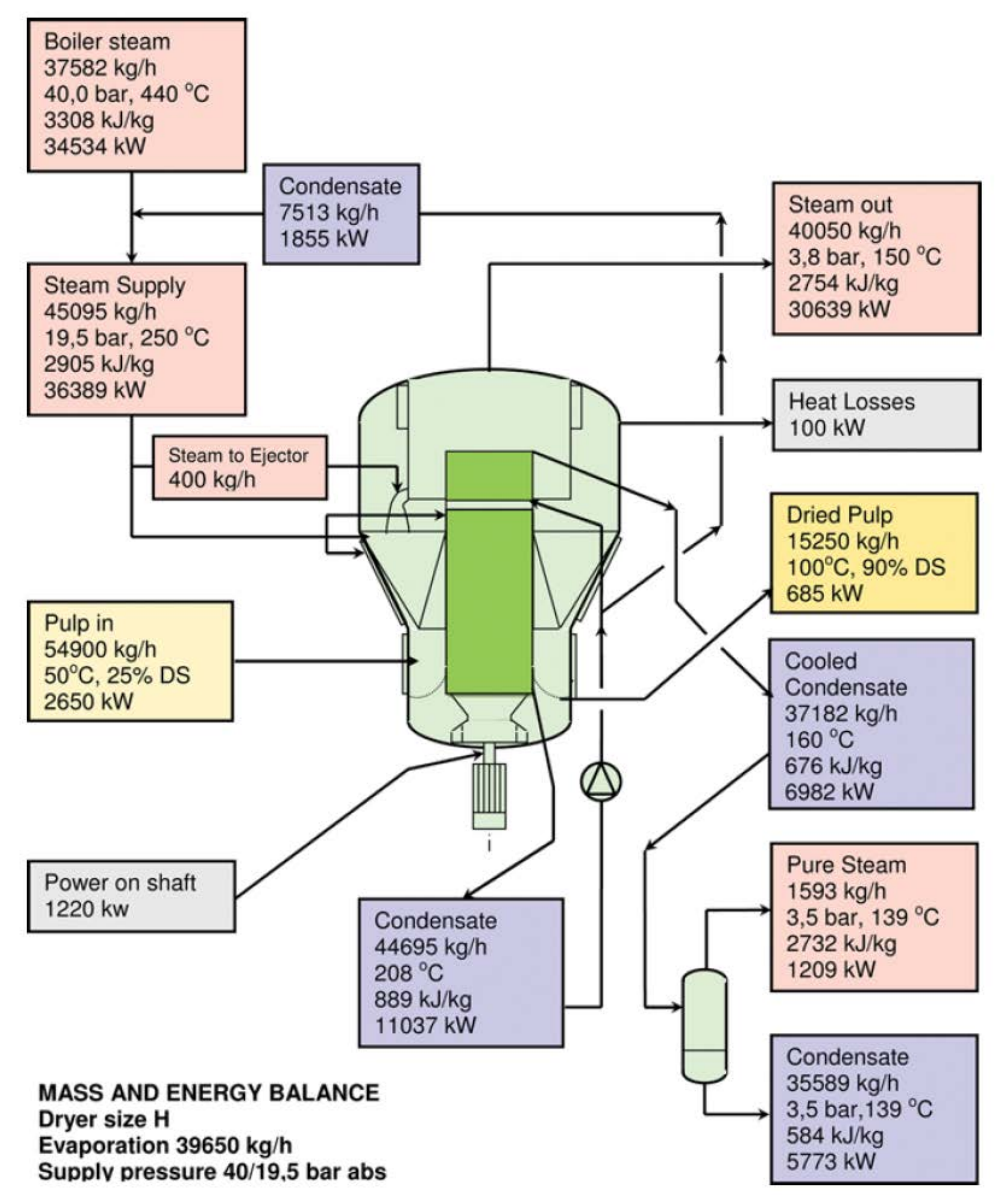

Fig. 4. Mass and energy balance of a size $\mathrm{H}$ steam dryer from EnerDry A/S drying sugar beet pulp. Reproduced from [21].

To simplify the modeling, a size independent dryer was used to calculate the pressure increase of the integrated steam blower ( $47 \mathrm{mbar}$ ) and then keeping it constant. The supply steam pressure was conservatively set at the maximum value ( 27 bar), while the hot side fluid of the top heat exchanger was changed from condensate to low-pressure steam in order to enable the mechanical vapor recompression (MVR) to supply part of the drying heat. This means that part of the excessive drying steam leaving the dryer in the top will be recompressed and used to heat the drying steam (Fig. 5). This combination of MVR and conventional heating of the drying steam will be referred to as "assisted MVR." The advantage of assisted MVR is that a very high coefficient of performance (COP) can be achieved, as shown in Fig. 6, because MVR only supplies the low-temperature part of the drying heat, but also because the steam blower consumption is kept constant. When only using MVR, there is a tradeoff between the MVR compressor power and the steam blower power. Figure 6 shows both the overall COP, defined as the heat release divided by the MVR compressor power, and the point or gradient COP value (COP'), which is defined as the change in heat release divided by the change in MVR compressor power. When heating the drying steam with MVR from $150{ }^{\circ} \mathrm{C}$ to $175^{\circ} \mathrm{C}$, which means that $35 \%$ of the drying heat demand is covered by MVR, a COP of 10 is achieved. This energy-efficient drying affects the overall system performance and dramatically reduces the system impact related to the use of very wet biomasses. 


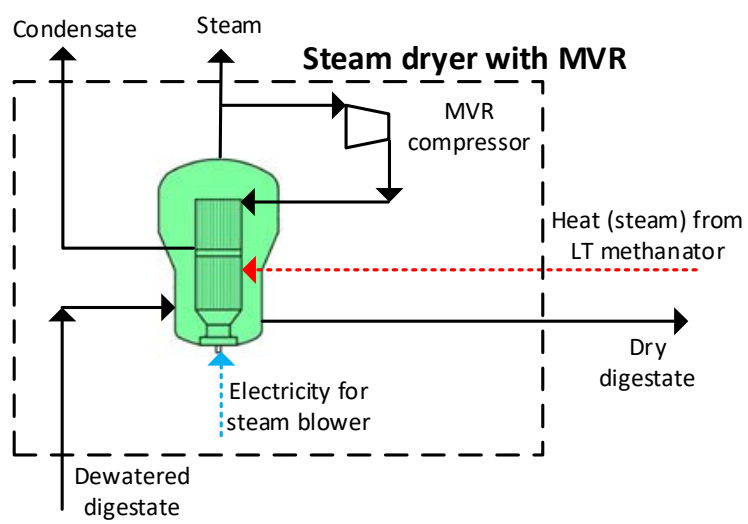

Fig. 5. Modified steam dryer used in the modeling approach. The top heat exchanger in the dryer uses low-pressure steam to enable "assisted MVR."

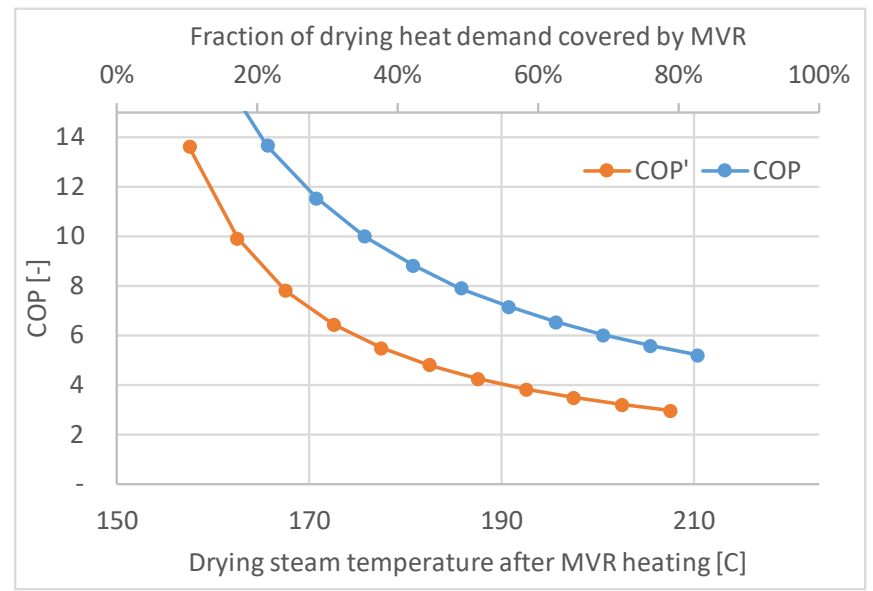

Fig. 6. Overall COP and point COP (COP') of assisted MVR used to heat drying steam at 4 bar from $150{ }^{\circ} \mathrm{C}$. The remaining heating (to $223^{\circ} \mathrm{C}$ ) is performed by the condensation of 27 bar steam $\left(228^{\circ} \mathrm{C}\right) . \mathrm{COP}^{\prime}$ is calculated based on the adjacent modeling data points.

\subsection{Gasifier}

A two-stage gasification process with high cold-gas efficiency is used for the production of tar-free syngas. The Two-Stage Gasifier from the Technical University of Denmark (DTU) has been demonstrated by the Viking Gasifier demonstration plant $[22,23]$. Several studies have been made on how to scale up the technology to commercial size $[24,25]$. A modified version of one of these designs, combining updraft pyrolysis and fluid bed char gasification, is employed in this paper. The dry manure or dry digested manure exits the steam dryer as granules [21], and it is assumed that these granules are big enough to be used in an updraft fixed bed pyrolysis. Alternatively, briquetting or pelletization could be used after the steam dryer, or fluid bed pyrolysis could be implemented. After the updraft pyrolysis, the pyrolysis gas is partially oxidized (POX) by oxygen from the electrolysis, all tars are converted in this process as the temperature reaches $1300^{\circ} \mathrm{C}$. The hot gas is then quenched with steam from the steam dryer in order to reach a suitable temperature for the injection into the fluid bed char reactor. The pyrolysis char is converted to gas by the reaction with $\mathrm{H}_{2} \mathrm{O}$ or $\mathrm{CO}_{2}$ present in the gas. It is important to keep the temperature low in the char reactor $\left(\sim 730^{\circ} \mathrm{C}\right)$ to avoid agglomeration when gasifying char with a high ash content. The fluid bed char reactor has been modelled based on the char reactor in the LTCFB gasifier, which has shown capability to gasify high ash biomasses, such as manure, digestate and sewage sludge [26]. The syngas product from the char reactor is split into two fractions and cooled by 
heat exchange with 1) steam and 2) pyrolysis gas in order to deliver the heat required for pyrolysis (Fig. 7).

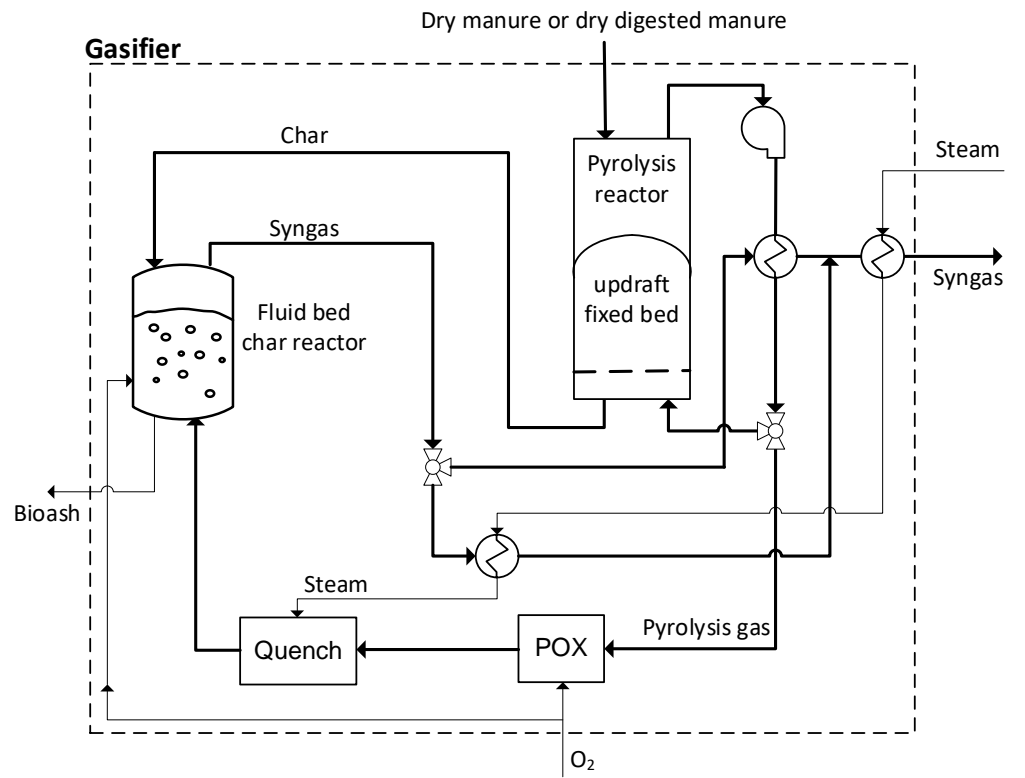

Fig. 7. Flowsheet of the used two-stage gasifier. $\mathrm{POX}=$ partial oxidation.

For the calculation of the outputs of gas and char from pyrolysis, experimental data on pyrolysis of "swine solids" were used [27] ${ }^{3}$. Swine solids represent the dry fraction from a solid-liquid separation of swine manure. For simplicity, these data were also used to model the pyrolysis of digested pig manure by keeping the char composition, heating value, and yield on a dry and ash-free basis (daf) fixed, while the ash content was allowed to vary. It is expected that the volatile fraction of digested manure is significantly lower than that of untreated manure. However, the result shows that the gasifier is extremely adaptable to lower volatile content, as oxidant $\left(\mathrm{O}_{2}\right)$ can be injected at POX and also directly into the fluid bed char reactor (Fig. 7). If the volatile fraction is reduced, more char is produced, and a greater fraction of the oxidant is sent to the char reactor instead of POX. If all the oxidant were sent to the POX, very high temperatures would be reached during the injection to the fluid bed, posing a problem for the injection nozzles. Therefore, a maximum gas temperature of $950{ }^{\circ} \mathrm{C}$ at the injection nozzles is assumed.

\subsection{Solid oxide electrolysis cells}

Solid oxide electrolysis cells (SOEC) are used for the co-electrolysis of $\mathrm{H}_{2} \mathrm{O}$ and $\mathrm{CO}_{2}$ present in the syngas in order to form $\mathrm{H}_{2}$ and $\mathrm{CO}$. Most of the $\mathrm{CO}$, catalyzed by nickel in the fuel electrode, reacts with $\mathrm{H}_{2}$ to form $\mathrm{CH}_{4}[4,28]$. Pressurized operation is necessary to push the equilibrium towards methane production $[4,28]$. The combination of the exothermic methane synthesis reaction and the endothermic electrolysis reactions results in a slightly exothermic stack operation. Pure oxygen is generated at the oxygen electrode. The oxygen is in part used by the gasifier. The stack cooling is primarily performed by having a high $\mathrm{H} / \mathrm{C}$ ratio ( 10$)$. Increasing the $\mathrm{H} / \mathrm{C}$ ratio will make the stack more endothermic due to

\footnotetext{
${ }^{3}$ The dry composition of the biochar product has been normalized due to inconsistencies (the dry composition is stated to be: $44.06 \% \mathrm{C}, 0.74 \% \mathrm{H}, 2.61 \% \mathrm{~N}, 0.85 \% \mathrm{~S}, 4.03 \% \mathrm{O}$, and $52.9 \%$ ash, summing-up $104.3 \%$ ). The normalization has been done while keeping the ash content fixed to $52.9 \%$. This results in a dry and ash-free composition of $85.65 \% \mathrm{C}, 1.44 \% \mathrm{H}, 5.07 \% \mathrm{~N}$, and $7.83 \%$ O. The char yield is $23.5 \mathrm{wt} \%$ (daf), and it has a HHV of $15.07 \mathrm{MJ} / \mathrm{kg}$ (dry) or $32.00 \mathrm{MJ} / \mathrm{kg}$ (daf). The experiments were performed at $700{ }^{\circ} \mathrm{C}$ [27].
} 
steam electrolysis reactions. The operating temperature is set to $750^{\circ} \mathrm{C}$ while the fuel inlet temperature is calculated by the upstream adiabatic reactor $\left(681-685^{\circ} \mathrm{C}\right)$. The SOEC cell voltage is calculated from the Nernst voltage and assumed values of ASR and current density, as shown in eq. 1-4.

$$
\begin{gathered}
V_{S O E C}=E_{\text {Nernst,average }}-A S R \cdot i_{\text {SOEC }} \\
E_{\text {Nernst,average }}=\frac{\Delta G}{I_{S O E C}} \\
E_{\text {Nernst }}=-\frac{\Delta G}{n_{e} \cdot F} \\
\dot{\Delta G}=\dot{m}_{f u e l, I N} g_{f u e l, I N}+\dot{m}_{\text {air }, I N} g_{\text {air }, I N}-\dot{m}_{f u e l, \text { OUT }} g_{f u e l, \text { OUT }}-\dot{m}_{\text {air }, \text { out }} g_{\text {air }, \text { OUT }}
\end{gathered}
$$

Where $i_{S O E C}$ is the current density, $I_{S O E C}$ is the total current, $\Delta G$ is the change in Gibbs free energy of a general electrochemical reaction, $n_{e}$ is the number of electrons transferred during the reaction, and $F$ is the Faraday constant. $\dot{m}$ is the mass flow and $g$ is the specific Gibbs free energy. It is important to note that the specific Gibbs free energies used in eq. (4) are calculated at the exit temperature $\left(750^{\circ} \mathrm{C}\right)$. Therefore, the model of the SOEC assumes an isothermal SOEC.

\subsection{Methane reactors}

Two adiabatic reactors and one cooled methane reactor are employed in the system. One adiabatic reactor is used upstream the SOEC to preheat the gas before the SOEC and also to produce an equilibrium gas in order to lower the thermal stress in the SOEC. The cooled methane reactor is used to convert the $\mathrm{CO}$ and $\mathrm{CO}_{2}$ in the methane-rich gas from the SOEC and the $\mathrm{CO}_{2}$ in the cleaned biogas to $\mathrm{CH}_{4}$.

The second adiabatic reactor is used to ensure a very high methane content suited for grid injection. This adiabatic reactor is needed because the nitrogen content is high, but also because the pressure in the cooled methane reactor is only 7-8 bar while the pressure in the following adiabatic reactor is set to 20 bar. The reactor temperature of the cooled methane reactor is calculated based on the needed temperature lift of the following adiabatic reactor in order to enable heat exchange between the reactant gas $\left(200^{\circ} \mathrm{C}\right)$ and the product gas $\left(240^{\circ} \mathrm{C}\right)$. Increasing the temperature of the cooled methane reactor will lower the methane production in that reactor but increase the methane production in the adiabatic reactor. The ratios between $\mathrm{H}_{2}, \mathrm{CO}$, and $\mathrm{CO}_{2}$ in the gas to the cooled methane reactor are set based on eq. 5 , where an $\mathrm{M}=3$ is the optimal value based on the chemical reaction equations (eq. 6-7).

$$
\begin{array}{ll}
M=\frac{\mathrm{H}_{2}-\mathrm{CO}_{2}}{\mathrm{CO}+\mathrm{CO}_{2}} & \\
\mathrm{CO}+3 \mathrm{H}_{2} \leftrightarrow \mathrm{CH}_{4}+\mathrm{H}_{2} \mathrm{O} & -206 \mathrm{~kJ} \\
\mathrm{CO}_{2}+4 \mathrm{H}_{2} \leftrightarrow \mathrm{CH}_{4}+2 \mathrm{H}_{2} \mathrm{O} & -165 \mathrm{~kJ}
\end{array}
$$


Table 1

Process design parameters and key assumptions used in the modeling.

\begin{tabular}{|c|c|}
\hline Feedstock & $\begin{array}{l}\text { Pig manure. The dry and ash-free composition is assumed to be }(w t \%): 56.72 \% \mathrm{C}, 7.19 \% \mathrm{H}, 31.17 \% \\
\mathrm{O} \text {, and } 4.92 \% \mathrm{~N}^{\mathrm{a}} \text {. The ash-content is } 20.90 \% \text { [27]. The sulfur content is neglected }{ }^{b} . \mathrm{HHV}=19.39 \\
\mathrm{MJ} / \mathrm{kg}_{\text {dry }}[27] . \mathrm{C}_{p}=1.35 \mathrm{~kJ} /\left(\mathrm{kg}_{\text {dry }}{ }^{*} \mathrm{~K}\right) . \text { Dry matter content }=8.3 \text { wt\%. }\end{array}$ \\
\hline Biogas reactor & 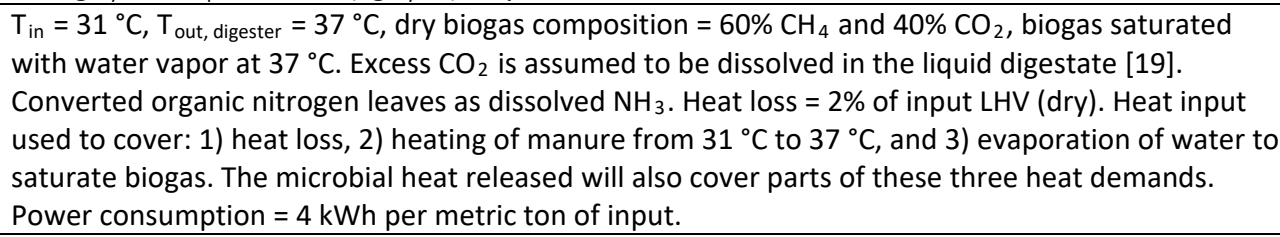 \\
\hline Dewatering decanter & $\begin{array}{l}\text { Dry matter separation efficiency }=68 \% \text { (pig slurry) or } 77 \% \text { (digestate) })^{c} \text {. Outlet dry matter content = } \\
30 \text { wt\%. Power consumption }=2.9 \text { (pig slurry) or } 2.2 \text { (digestate) } k W h \text { per metric ton of input [29]. }\end{array}$ \\
\hline Steam dryer & $\begin{array}{l}\mathrm{P}_{\text {dryer }}=4 \text { bar. Moisture content after drying }=2 \mathrm{wt} \%^{\mathrm{d}} . \mathrm{T}_{\text {out, biomass }}=144^{\circ} \mathrm{C} . \text { Steam blower power } \\
\text { consumption based on measured data [21]. }\end{array}$ \\
\hline Gasifier & $\begin{array}{l}\Delta \mathrm{P}=0.4 \text { bar. Carbon conversion }=95 \% \text {. Heat loss }=2 \% \text { of the biomass thermal input (LHV dry). } \mathrm{T}_{\text {exit }} \\
\text { char reactor }=730^{\circ} \mathrm{C} . \mathrm{T}_{\text {exit, }} \text { char pyrolysis reactor }=670^{\circ} \mathrm{C} \text {. The gas }\left(\mathrm{excl} . \mathrm{CH}_{4}\right) \text { is assumed to be in } \\
\text { chemical equilibrium at the outlet of the char reactor }\left(730^{\circ} \mathrm{C}\right) . \mathrm{CH}_{4} \text { content of dry syngas }=0.01 \\
\text { mole }{ }^{\mathrm{e}} . \mathrm{c}_{\mathrm{p}} \text { of ash }=1 \mathrm{~kJ} /\left(\mathrm{kg}{ }^{*} \mathrm{~K}\right) \text {. Minimum steam content at gasifier outlet }=20 \text { vol\%. }\end{array}$ \\
\hline SOEC & $\begin{array}{l}\text { Operating/exit temperature }=750{ }^{\circ} \mathrm{C} \text {. Operating pressure }=7.0-7.7 \text { bar }{ }^{f} \text {. Pressure loss }=30 \mathrm{mbar} \\
\text { [30]. } 10 \mathrm{~mol} \% \mathrm{H}_{2} \mathrm{O}+\mathrm{CO}_{2} \text { in outlet fuel gas. ASR }=0.20 \Omega \mathrm{cm}^{2} . \text { Current density }=0.5 \mathrm{~A} / \mathrm{cm}^{2} . \text { Heat loss } \\
=1 \% \text { of input electricity. AC-DC converter efficiency }=99 \% .\end{array}$ \\
\hline Compressor/turbine & $\eta_{\text {isentropic, compressor }}=88 \%, \eta_{\text {isentropic, turbine }}=90 \%, \eta_{\text {isentropic, blower }}=50 \%$ \\
\hline Methane reactors & $\begin{array}{l}\text { Chemical equilibrium at reactor outlet temperature and pressure. The reactor outlet temperature } \\
\text { of boiling water reactor is minimum } 280^{\circ} \mathrm{C} \text {, the reactor outlet temperature of the final adiabatic } \\
\text { reactor is } 240^{\circ} \mathrm{C} \text {. Pressure in final adiabatic reactor }=20 \text { bar. }\end{array}$ \\
\hline Heat exchangers & $\begin{array}{l}\Delta \mathrm{T}_{\min }=30{ }^{\circ} \mathrm{C} \text { (gas-gas), } \Delta \mathrm{T}_{\min }=10^{\circ} \mathrm{C} \text { (gas-liq or gas-condens. gas), } \Delta \mathrm{T}_{\min }=5^{\circ} \mathrm{C} \text { (gas- } \\
\text { boiling/condensing water), } \Delta \mathrm{T}_{\min }=4{ }^{\circ} \mathrm{C} \text { (liq-liq) }\end{array}$ \\
\hline
\end{tabular}

a The composition given in reference [27] is for "swine solids." The dry composition has been normalized due to inconsistencies (the dry composition is stated to be: $47.42 \% \mathrm{C}, 6.01 \% \mathrm{H}, 4.11 \% \mathrm{~N}, 0.94 \% \mathrm{~S}, 26.07 \% \mathrm{O}$, and $20.9 \%$ ash, summing-up to $104.51 \%$ ). The normalization has been done while keeping the ash content fixed to $20.9 \%$. The composition matches well with data regarding biomass and waste from the Phyllis2 database, especially sample \#1366 "pig manure." However, there are significant variations among pig manure samples. Reference [27] was chosen because it contains pyrolysis data on biochar yield and composition, which is needed for the gasifier modeling.

${ }^{b}$ The sulfur content is neglected. The sulfur content of pig manure is usually $0.5-1$ wt\% (dry) [20].

c The stated separation efficiencies are called simple separation efficiencies, defined as dry matter (DM) in the dewatered output divided by the dry matter in the input slurry. These values are calculated based on reduced separation efficiencies: $64 \%$ (pig slurry) and 74\% (anaerobically digested slurry), as reported in [29]. The reduced separation efficiency is defined as: $E_{t}{ }^{\prime}=$ $\frac{E_{t}-R_{f}}{1-R_{f}}$, where $\mathrm{E}_{\mathrm{t}}$ is the simple separation efficiency and $\mathrm{R}_{\mathrm{f}}$ is a mass ratio defined as the dewatered output divided by the input slurry [29]. By assuming $R_{f}=0.124$ based on measurements reported in [31] for pig slurry using a decanter centrifuge, the simple separation efficiencies can be calculated. Note that the simple separation efficiencies cannot be lower than the reduced separation efficiencies. For comparison, the simple separation efficiency of pig slurry is measured as $60.9 \%$ in [31]. All these data were obtained without the use of polymer to enhance separation efficiency.

${ }^{d}$ The moisture content after drying is listed as $10 \mathrm{wt} \%$ in Fig. 4 (90\% DS). It is assumed that this can be lowered to 2 wt\% by the reduction of the biomass feeding rate. A moisture content of $10 \mathrm{wt} \%$ is suitable for downstream palletization, which is the conventional downstream process used to make animal feed from the dried sugar beet pulp.

e The methane content will be lower than that calculated by chemical equilibrium because the very high partial oxidation temperature $\left(\sim 1300^{\circ} \mathrm{C}\right)$ will convert all the methane. The methane formation reactions that occur in the following char reactor are very slow, so the methane content will not reach equilibrium.

${ }^{f}$ The pressure is set to the maximum possible value in the base case system. The pressure is constrained by the mass flow of steam available from the steam dryer. The pressure is set to the minimum possible value in the system without a biogas plant. In this case, the pressure is constrained by the minimum temperature of the boiling water methane reactor.

${ }^{\mathrm{g}}$ The methanation catalysts from Haldor Topsøe can operate at a temperature span of $190{ }^{\circ} \mathrm{C}$ to $>700{ }^{\circ} \mathrm{C}[32,33]$. 


\section{Results and discussion}

The results of the thermodynamic modeling of the two systems are presented in the following section. Key results are summarized in Grassmann diagrams (Fig. 8) showing how chemical energy in manure is converted to chemical energy in the product bio-SNG. The diagrams show that more chemical energy exits as bio-SNG than is used in the form of manure, which is possible due to the addition of electrical energy to the SOEC. Significantly more bio-SNG is produced when integrating biogas (138\% vs. 107\%) mainly because the loss of chemical energy with the liquid effluent from the decanter is lower ( $32 \%$ vs. $11 \%)$ and the flow of chemical energy going through the decanter centrifuge is smaller. Another significant difference between the two systems is the loss of chemical energy in the LT methanator. The loss is smaller in the system with biogas (16\% vs. $11 \%$ ) because biogas is already in the form of methane, while syngas needs to be upgraded to methane in an exothermic process. Compared with a stand-alone anaerobic digester, the output of bio-SNG is nearly tripled by the utilization of the digestate and integrating electrolysis (49\% vs. $138 \%$ ).

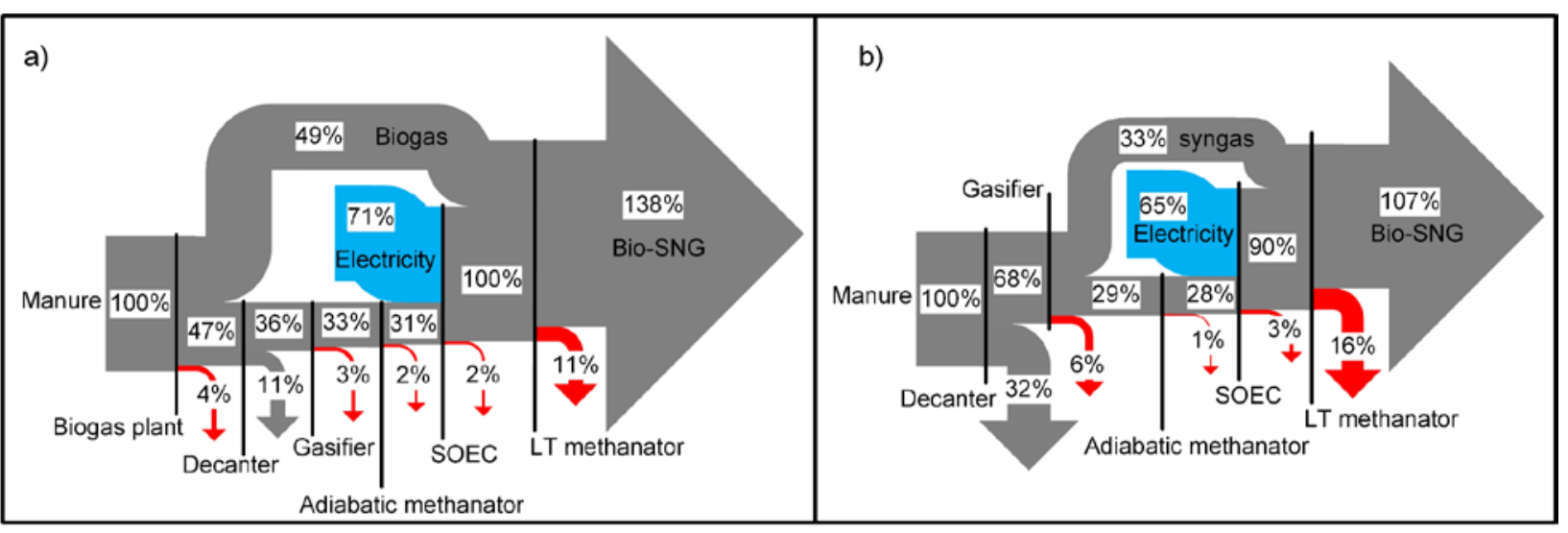

Fig. 8. Grassmann diagrams of the chemical energy flows $\left(L_{H V} V_{\text {dry }}\right)$ in the a) base case system with biogas and b) the system without biogas. Note that the electricity input to the SOEC is also shown (blue), as well as the loss of chemical energy at each conversion step (red).

The data behind the Grassman diagram for the base case system with biogas can be found in the corresponding detailed flowsheet (Fig. 9). The gas compositions of the main flows can be found in Table 2. Full-detail flowsheets for both systems are supplied in the appendix. To simplify the base system layout, it was decided to let all the biogas bypass the SOEC and only let syngas go to the SOEC. This led to a specific biomass conversion in the biogas reactor of $\left.53 \%\left(51.5 \mathrm{MW}_{\text {th }}-24.3 \mathrm{MW}_{\text {th }}\right) / 51.5 \mathrm{MW}_{\text {th }}\right)$. In a real biogas plant, the conversion will fluctuate a bit and could be higher or lower than this value. Therefore, the system needs valves and piping to be able to bypass some of the syngas in case of a lower conversion in the biogas reactor, and able to send some of the biogas to the SOEC in case of a higher conversion. 


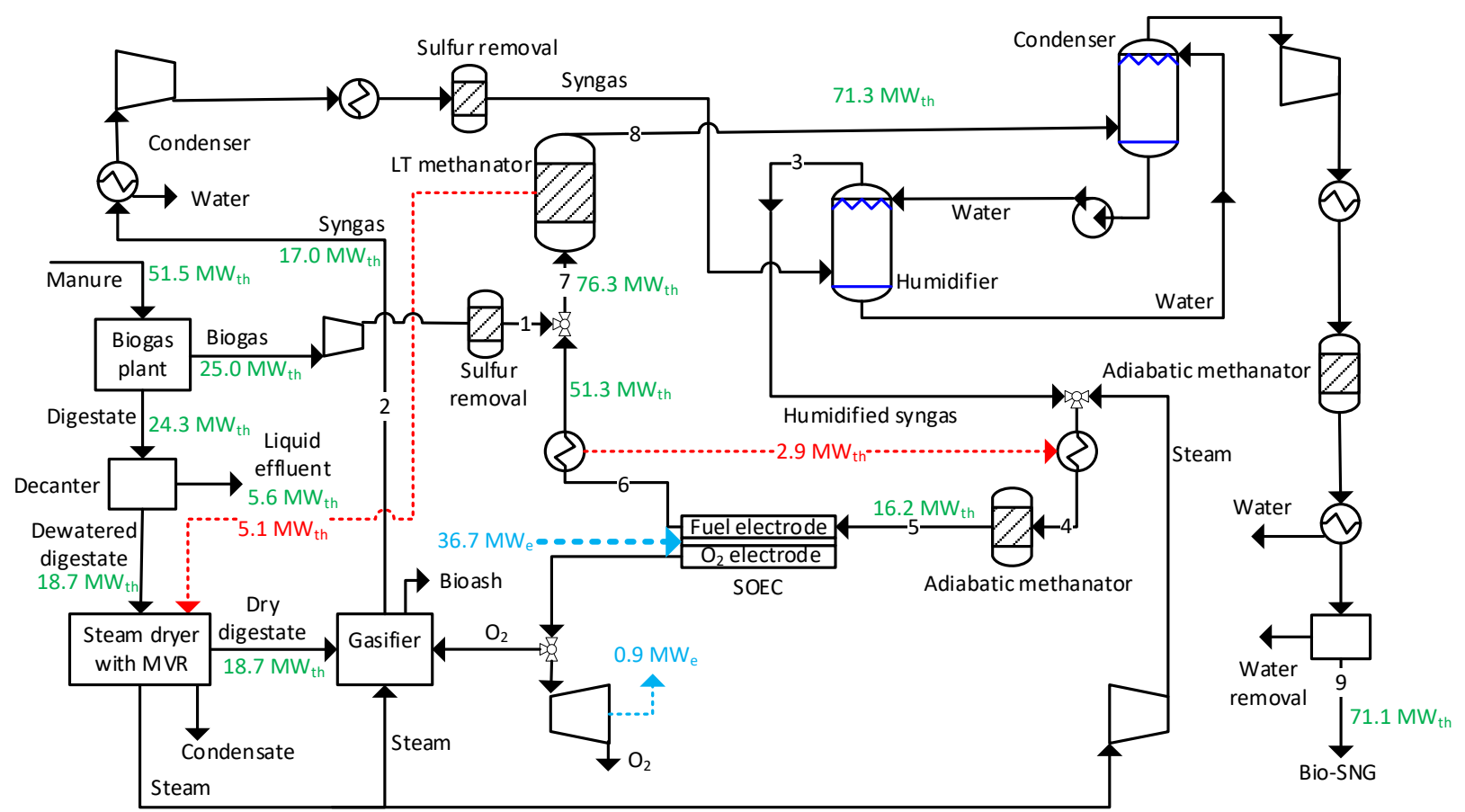

Fig. 9. Flowsheet of the manure to bio-SNG conversion system with all process steps. The figure includes major electricity consumptions and productions (blue), as well as chemical energy flows (LHV dry, green) and major heat flows (red). Stream numbers refer to Table 2 (with gas compositions). A more detailed flowsheet can be found in the appendix.

Table 2

Gas compositions (stream numbers refer to Fig. 9)

\begin{tabular}{|c|c|c|c|c|c|c|c|c|c|}
\hline & Biogas & $\begin{array}{r}\text { Gasifier } \\
\text { outlet }\end{array}$ & $\begin{array}{r}\text { Humidifier } \\
\text { outlet }\end{array}$ & $\begin{array}{r}\text { Adiabatic } \\
\text { methanator } \\
\text { inlet }\end{array}$ & $\begin{array}{r}\text { SOEC } \\
\text { fuel } \\
\text { inlet }\end{array}$ & $\begin{array}{r}\text { SOEC } \\
\text { fuel } \\
\text { outlet } \\
\end{array}$ & $\begin{array}{r}\mathrm{LT} \\
\text { methanator } \\
\text { inlet }\end{array}$ & $\begin{array}{r}\mathrm{LT} \\
\text { methanator } \\
\text { outlet }\end{array}$ & $\begin{array}{l}\text { Bio- } \\
\text { SNG }\end{array}$ \\
\hline $\begin{array}{l}\text { Stream } \\
\text { number }\end{array}$ & 1 & 2 & 3 & 4 & 5 & 6 & 7 & 8 & 9 \\
\hline $\begin{array}{l}\text { Mass flow } \\
{[\mathrm{kg} / \mathrm{s}]}\end{array}$ & 1.48 & 1.76 & 2.67 & 3.87 & 3.87 & 1.26 & 2.74 & 2.74 & 1.46 \\
\hline $\begin{array}{l}\text { Mole flow } \\
{[\text { mole } / \mathrm{s}]}\end{array}$ & 56 & 103 & 154 & 220 & 218 & 166 & 221 & 163 & 90 \\
\hline \multicolumn{10}{|l|}{ Mole\% } \\
\hline$\overline{\mathrm{H}_{2}}$ & & 43.1 & 28.9 & 20.2 & 25.1 & 67.9 & 50.8 & 2.5 & 0.3 \\
\hline $\mathrm{CO}$ & & 21.4 & 14.4 & 10.0 & 3.3 & 4.8 & 3.6 & $\sim 0^{\mathrm{a}}$ & $\sim 0^{b}$ \\
\hline $\mathrm{CO}_{2}$ & 37.5 & 14.1 & 9.4 & 6.6 & 13.0 & 0.8 & 10.0 & 0.6 & $\sim 0$ \\
\hline $\mathrm{H}_{2} \mathrm{O}$ & 6.3 & 20.0 & 46.4 & 62.5 & 57.5 & 9.2 & 8.4 & 42.2 & $\sim 0$ \\
\hline $\mathrm{CH}_{4}$ & 56.2 & $\sim 0$ & $\sim 0$ & $\sim 0$ & 0.6 & 16.5 & 26.5 & 53.7 & 98.0 \\
\hline $\mathrm{N}_{2}$ & & 1.4 & 0.9 & 0.7 & 0.7 & 0.9 & 0.6 & 0.9 & 1.6 \\
\hline
\end{tabular}

a 8 ppm CO. ${ }^{\text {b } 0.8 ~ p p m ~ C O . ~}$

Energy inputs and outputs to the system, as well as key energy efficiencies and energy ratios, can be found in Table 3 and Table 4. The total energy efficiency from manure and electricity input to bio-SNG output is calculated to be $79 \%$ for the base system with biogas and $64 \%$ for the system without biogas. The main reason for the difference is the loss of chemical energy from the decanter, as was previously shown on the Grassmann diagrams. Moreover, the high energy efficiency of the system with biogas is due to the high efficiency of the gasifier (91\%) and SOEC (96\%), as well as the internal methanation in the SOEC, which lowers the electricity consumption of the SOEC. Finally, the steam drying with assisted 
MVR only requires a small electricity input $(0.5 \mathrm{MW})$ to cover about a third of the drying heat demand by MVR. In summary, this means that for every $100 \mathrm{MJ}$ of bio-SNG produced, the system with biogas requires $72 \mathrm{MJ}$ of manure, while the system without biogas requires $93 \mathrm{MJ}$. The system with biogas also requires less electricity (54 MJ vs. $63 \mathrm{MJ})$.

The steam dryer uses the integrated MVR system to cover about a third of the dryer heat demand by MVR, which results in a COP of 10.5 and 11.1 for the two systems (see also Fig. 6). The system without biogas has a significantly higher drying heat demand (12.4 MW vs. 7.8 MW), but this is almost compensated by the higher heat release from the LT methanator, as seen on the flowsheets and the Grassmann diagram.

In both cases, the SOEC operates with a high $\mathrm{H} / \mathrm{C}$ ratio of 10.0-10.3 (Table 5), which is calculated by the cooling demand of the SOEC. The $\mathrm{H} / \mathrm{C}$ ratio is high enough to avoid equilibrium carbon formation, which is predicted by thermodynamics to occur at an $\mathrm{H} / \mathrm{C}$ ratio lower than 8.4 (at $750{ }^{\circ} \mathrm{C}$ and 7 bar). The oxygen utilization factor is calculated to be $86-87 \%$, which is considered reasonable for future SOEC applications.

\section{Table 3}

Energy inputs and outputs of the two systems

\begin{tabular}{|c|c|c|}
\hline & Biogas+gasifier+SOEC & Gasifier+SOEC \\
\hline Manure input [MWth] (dry basis) & 51.5 & 51.5 \\
\hline \multicolumn{3}{|l|}{ Electricity consumption: [MWe] } \\
\hline Electrolysis & 36.7 & 33.4 \\
\hline Steam dryer (blower) ${ }^{a}$ & 0.3 & 0.4 \\
\hline Steam dryer (MVR compressor) ${ }^{\mathrm{a}}$ & 0.2 & 0.3 \\
\hline Oxygen turbine & -0.9 & -0.7 \\
\hline Other components (compressors, blowers, pumps) & 1.9 & 1.2 \\
\hline Net electricity consumption & 38.2 & 34.6 \\
\hline Bio-SNG production [MWth] & 71.1 & 55.2 \\
\hline
\end{tabular}

${ }^{a}$ Note that in practice the steam dryer from Enerdry A/S will have a minimum blower consumption of $430 \mathrm{~kW}$ corresponding to a size $\mathrm{E}$ dryer. However, the increase in blower consumption is somewhat compensated by a decrease in MVR compressor consumption, as the steam pressure after the MVR compressor is reduced.

\section{Table 4}

Energy efficiencies and energy ratios of the two systems

\begin{tabular}{|c|c|c|}
\hline Energy efficiencies [\%]: & Biogas+gasifier+SOEC & Gasifier+SOEC \\
\hline Cold gas efficiency ${ }^{a}$ & 91 & 92 \\
\hline SOEC efficiency ${ }^{b}$ & 96 & 96 \\
\hline LT methanator efficiency ${ }^{a}$ & 93 & 87 \\
\hline $\begin{array}{l}\text { Manure + electricity to SNG } \\
\text { (total efficiency) }\end{array}$ & 79 & 64 \\
\hline Gas upgrading efficiency ${ }^{c}$ & 84 & 83 \\
\hline \multicolumn{3}{|l|}{ Energy ratios [\%]: } \\
\hline Manure to SNG & 138 & 107 \\
\hline Electricity to SNG & 186 & 159 \\
\hline Manure per SNG output & 72 & 93 \\
\hline Electricity per SNG output & 54 & 63 \\
\hline
\end{tabular}

a Defined as output heating value flow divided by input heating value flow: $\frac{\dot{m}_{\text {out }} \cdot L H V_{\text {out }}}{\dot{m}_{\text {in }} \cdot L H V_{\text {in }}} .{ }^{\text {b }}$ Defined as the increase in heating

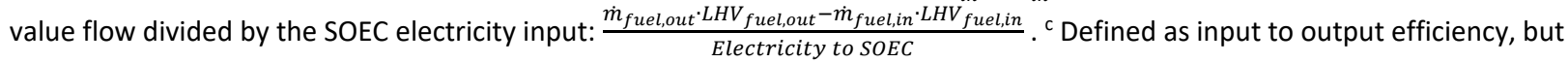
excluding biogas as the methane in biogas is not upgraded: $\frac{\dot{m}_{\text {biomethane }} \cdot L H V_{\text {biomethane }}-\dot{m}_{\text {biogas }} \cdot L H V_{\text {biogas }}}{\dot{m}_{\text {syngas }} \cdot L V_{\text {syngas }}+\text { net electricity }}$. 
Table 5

Calculated SOEC parameters

\begin{tabular}{lrr}
\hline & Biogas+gasifier+SOEC & Gasifier+SOEC \\
Oxygen utilization factor & $86.3 \%$ & $87.2 \%$ \\
H/C molar ratio & 10.0 & 10.3 \\
Cell voltage [V] & 1.156 & 1.157 \\
$E_{\text {Nernst, average }}[\mathrm{V}]$ & 1.056 & 1.057 \\
$E_{\text {Nernst, inlet }}[\mathrm{V}]$ & 0.999 & 1.000 \\
$E_{\text {Nernst, outlet }}[\mathrm{V}]$ & 1.123 & 1.124 \\
Total active cell area $\left[\mathrm{m}^{2}\right]$ & 6290 & 5718 \\
\hline
\end{tabular}

The quality of the produced bio-SNG varies greatly between the two systems. The system with biogas has a methane content of 98.0 vol\%, while it is 95.9 vol\% in the other system (Table 6). This is due to a large difference in nitrogen content ( $1.6 \mathrm{vol} \% \mathrm{vs.} 3.8 \mathrm{vol} \%$ ) caused by a fundamental difference between anaerobic digestion and thermal gasification. Anaerobic digestion is normally operated in a manner that avoids free nitrogen in the produced biogas. Instead, the converted organic nitrogen leaves the reactor with the digestate as ammonia (or ammonium). In thermal gasification, nearly all nitrogen in the input biomass is converted to $\mathrm{N}_{2}$ and mixed with the syngas. The high nitrogen content in the bio-SNG produced by the system without biogas lowers the Wobbe index of the bio-SNG just below the acceptable level for natural gas in Denmark [34], but would still be acceptable in other countries (e.g., Germany).

The high nitrogen content is because of the use of pig manure, while cow manure has a nitrogen content around half that of pig manure. Co-processing of straw or other biomasses could also lower the nitrogen content in the produced bio-SNG.

Table 6

Bio-SNG quality

\begin{tabular}{lrr}
\hline & Biogas+gasifier+SOEC & Gasifier+SOEC \\
\hline Methane content [mole\%] & 98.0 & 95.9 \\
Nitrogen content [mole\%] & 1.6 & 3.8 \\
Wobbe index [MJ/Nm $]^{\mathrm{a}}$ & 52.03 & 50.48 \\
Relative density, d [-] $]^{\mathrm{a}}$ & 0.562 & 0.571 \\
\hline
\end{tabular}

${ }^{\text {a }}$ Wobbe index $=\frac{H H V\left[\frac{M J}{N m^{3}}\right]}{\sqrt{d}}$, the relative density or specific gravity is calculated by assuming ideal gas: $\mathrm{d}=\frac{\text { density of gas }}{\text { density of air }}=$ $\frac{\text { molar mass of gas }}{\text { molar mass of air }}$. The gas regulations in Denmark are stricter than in other countries (e.g., Germany). In Denmark, the Wobbe Index must be higher than $50.76 \mathrm{MJ} / \mathrm{Nm}^{3}$ (HHV) and the relative density must be higher than 0.555 [34].

It should be noted that the ammonia content in the dewatered manure or digestate has not been included in the modeling. There is approximately the same amount of mineralized N (ammonia) as organic $\mathrm{N}$ in the dewatered product. The ammonia will evaporate in the steam dryer and leave the dryer mainly in the excess steam flow, but also dissolved in the condensate due to the use of MVR.

Commercial processes for the removal of ammonia from steam and liquid water exist [35]. In particular, the removal of ammonia from steam could result in a small net income as the captured ammonia can be sold as fertilizer [35].

For large-scale applications, a system with anaerobic digestion is considered infeasible. Nonetheless, an alternative to removing the anaerobic digester, as done in the Gasifier + SOEC system, could be implemented with the digesters and mechanical dewatering decentralized and then a central plant 
producing bio-SNG based on thermal gasification of the dewatered digestate. However, to avoid $\mathrm{CO}_{2}$ emissions from the biogas plants, upgrading to methane with electrolytic hydrogen would be needed in the biogas plants. This solution is pursued by Haldor Topsøe A/S. When converting the $\mathrm{CO}_{2}$ in the biogas to methane, the methane energy yield per manure input is increased from $49 \%$ for a stand-alone anaerobic digester to $82 \%$ (biogas with $40 \% \mathrm{CO}_{2}$ ) and the total energy efficiency is estimated to be $58 \%{ }^{4}$. If a centralized conversion of dewatered digestate is included, the total efficiency would increase to $76 \%$, and the total methane energy yield per manure input would be the same as the combined system analyzed in this paper (138\%).

A detailed techno-economic analysis would be needed in order to compare these different options. Future experimental work should include testing of key elements of the system, such as: 1) operating a steam dryer with dewatered digestate; 2 ) operating a fixed bed pyrolysis and fluid bed char gasifier on dry digestate; 3 ) research in pressurized SOEC. The last point requires the greatest effort, as this is a relatively new area.

\subsection{Comparison with previous work}

The two systems analyzed in this paper have a highly integrated design, comprising the three key technologies: 1) anaerobic digestion, 2) gasification and 3) pressurized SOEC with internal methanation, but also 4) steam drying is needed to enable an energy efficient drying, resulting in the high overall efficiency. Finally 5) methanation is needed in order to reach grid quality SNG. Because the design consists of an integration of all these technologies, it is challenging to compare with previous studies as they typically differ significantly on the technologies used and how they are integrated. It is however possible to compare with systems with the same inputs and outputs, in this case systems that can convert biomass and electricity to bio-SNG. In Table 7 such a comparison is made. Only one of the previous studies use a similar wet biomass, and this study does not include the dewatering stage, which means that if the loss of biomass in the decanter is included in that study the biomass to SNG energy ratio would drop from $165 \%$ to $112 \%$ and the total efficiency from $69-70 \%$ to $58-59 \%$. The other three previous studies are based on wood gasification, and therefore has a clear advantage of avoiding the decanter dewatering stage. Given this advantage, the new novel systems based on manure utilization compares well with the wood based systems. Only one of the previous studies obtains a higher total efficiency. One of the reasons is that two of the previous studies use liquid water electrolysis, which has a lower efficiency than steam electrolysis used in the study from 2017, and a much lower efficiency than the pressurized co-electrolysis used in the present work. The pressurized co-electrolysis benefits from the internal methanation happening in the pressurized SOEC cells. It should be noted that the study by Martínez et al. only incorporates very little electricity through electrolysis, and therefore has a very low biomass to SNG energy ratio of $68 \%$.

\footnotetext{
${ }^{4} \mathrm{CO}_{2}$ is converted to $\mathrm{CH}_{4}$ by the addition of $\mathrm{H}_{2}$ from steam electrolysis followed by a catalytic methane reactor. The steam needed for the electrolysis is generated by cooling the methane reactor. The conversion from $\mathrm{CO}_{2}$ to $\mathrm{CH}_{4}$ by the reaction $\mathrm{CO}_{2}+4 \mathrm{H}_{2}>\mathrm{CH}_{4}+2 \mathrm{H}_{2} \mathrm{O}$ has an LHV efficiency of $83 \%$. An efficiency of steam electrolysis of $95 \%$ (LHV) is assumed. Considering a manure input of $100 \mathrm{MJ}, 49 \mathrm{MJ}$ of methane is produced by anaerobic digestion and 33 $\mathrm{MJ}$ of methane is produced from $\mathrm{CO}_{2}$. To produce the $33 \mathrm{MJ}$ methane, $40 \mathrm{MJ}$ of hydrogen is needed, corresponding to an electricity input of $42 \mathrm{MJ}$. The total efficiency is then $\frac{49+33}{100+42}=58 \%$.
} 
Table 7

Comparison of the two systems with published systems that convert biomass and electricity to SNG

\begin{tabular}{|c|c|c|c|c|c|c|}
\hline & $\begin{array}{r}\text { Biogas+gasifier } \\
+ \text { SOEC }\end{array}$ & Gasifier+SOEC & $\begin{array}{r}\text { Clausen et al., } \\
2019 \text { [7] }\end{array}$ & Clausen, 2017 [6] & $\begin{array}{r}\text { Martínez et } \\
\text { al., } 2016 \text { [13] }\end{array}$ & $\begin{array}{r}\text { Gassner et } \\
\text { al., 2008 [12] }\end{array}$ \\
\hline Biomass type & manure & manure & Wood pellets & $\begin{array}{r}\text { Dewatered } \\
\text { digestate/sludge }\end{array}$ & Wood & Wood \\
\hline $\begin{array}{l}\text { Biomass moisture } \\
\text { content [wt\%] }\end{array}$ & 92 & 92 & 7 & 70 & $\begin{array}{r}\text { Dry (not } \\
\text { stated) }\end{array}$ & 50 \\
\hline Gasifier type & $\begin{array}{r}\text { Fixed bed } \\
\text { pyrolysis and } \\
\text { fluid bed char } \\
\text { gasification }\end{array}$ & $\begin{array}{r}\text { Fixed bed } \\
\text { pyrolysis and } \\
\text { fluid bed char } \\
\text { gasification }\end{array}$ & $\begin{array}{r}\text { Fixed bed } \\
\text { pyrolysis and } \\
\text { fixed bed char } \\
\text { gasification }\end{array}$ & $\begin{array}{r}\text { TwoStage } \\
\text { Gasifier (Viking) }\end{array}$ & $\begin{array}{l}\text { Indirectly } \\
\text { heated with } \\
\mathrm{CaO} \text { in bed } \\
\text { material }\end{array}$ & $\begin{array}{r}\text { Two cases: } \\
\text { Indirectly } \\
\text { heated or } \\
\text { oxygen } \\
\text { blown }\end{array}$ \\
\hline Electrolyzer type & $\begin{array}{r}\text { Pressurized co- } \\
\text { electrolysis } \\
(\mathrm{SOEC})\end{array}$ & $\begin{array}{r}\text { Pressurized } \\
\text { co-electrolysis } \\
\text { (SOEC) }\end{array}$ & $\begin{array}{r}\text { Pressurized } \\
\text { co-electrolysis } \\
\text { (SOEC) }\end{array}$ & $\begin{array}{r}\text { Steam } \\
\text { electrolysis } \\
(\mathrm{SOEC})\end{array}$ & $\begin{array}{r}\text { Water } \\
\text { electrolysis }\end{array}$ & $\begin{array}{r}\text { Water } \\
\text { electrolysis }\end{array}$ \\
\hline $\begin{array}{l}\text { Biomass + net } \\
\text { electricity to SNG } \\
\text { (total efficiency) [\%] }\end{array}$ & 79 & 64 & 84 & $69-70$ & 61 & 66 and $69^{a}$ \\
\hline $\begin{array}{l}\text { Biomass to SNG } \\
\text { energy ratio [\%] }\end{array}$ & 138 & 107 & 174 & 165 & 68 & 149 and 155 \\
\hline
\end{tabular}

\section{Conclusion}

In this study, thermodynamic modeling and analysis of two energy systems producing bio-SNG from manure were performed. The results highlight the potential increase in both energy efficiency and yield compared with a conventional stand-alone anaerobic digester. In terms of energy yield per manure input, the yield of bio-SNG increases from $49 \%$ for a conventional stand-alone anaerobic digester to $138 \%$ when converting the digestate to gas by thermal gasification, and upgrading the syngas and biogas to bio-SNG by pressurized electrolysis and catalytic conversion. Removing the anaerobic digester and thermally gasifying the manure instead, lowers the yield to $107 \%$ due to a loss of organic matter in the mechanical dewatering of manure. The total energy efficiency accounts for the electricity input to the electrolyzer, being $79 \%$ for the integrated system with anaerobic digestion and $64 \%$ for the system without it. This can, to some extent, be compared with $49 \%$ for the stand-alone anaerobic digester, although it requires further energy input for upgrading biogas to bio-SNG and for heating the digester. The main reasons for the high efficiency for the integrated system with anaerobic digestion are: 1) the use of steam drying, which produces steam for gasification, electrolysis, and mechanical vapor recompression (MVR); 2) the use of an efficient two-stage gasifier producing a tar-free syngas; and 3) the use of pressurized solid oxide cells for syngas upgrading, as internal methanation within the cells lowers the power consumption. These advanced systems may be attractive in the future in order to limit biomass consumption and to store renewable electricity as chemical fuels. 


\section{References}

[1] Boldrin A, Baral KR, Fitamo T, Vazifehkhoran AH, Jensen IG, Kjærgaard I, et al. Optimised biogas production from the co-digestion of sugar beet with pig slurry: Integrating energy, GHG and economic accounting. Energy 2016;112:606-17.

[2] Thomsen TP, Sárossy Z, Ahrenfeldt J, Henriksen UB, Frandsen FJ, Müller-Stöver DS. Changes imposed by pyrolysis, thermal gasification and incineration on composition and phosphorus fertilizer quality of municipal sewage sludge. J Environ Manage 2017;198:308-18.

[3] Li X, Rubæk GH, Müller-Stöver DS, Thomsen TP, Ahrenfeldt J, Sørensen P. Plant Availability of Phosphorus in Five Gasification Biochars. Front Sustain Food Syst 2017;1:1-12.

[4] Jensen SH, Langnickel H, Hintzen N, Chen M, Hauch A, Butera G, et al. Pressurized reversible operation of a 30-cell solid oxide cell stack using carbonaceous gases. European Fuel Cell Technology \& Applications Conference - Piero Lunghi Conference, ENEA; 2017.

[5] Butera G, Jensen SH, Clausen LR. A novel system for large-scale storage of electricity as synthetic natural gas using reversible pressurized solid oxide cells. Energy 2019;166:738-54.

[6] Clausen LR. Energy efficient thermochemical conversion of very wet biomass to biofuels by integration of steam drying, steam electrolysis and gasification. Energy 2017;125.

[7] Clausen LR, Butera G, Jensen SH. High efficiency SNG production from biomass and electricity by integrating gasification with pressurized solid oxide electrolysis cells. Energy 2019.

[8] Li W, Lu C, An G, Zhang Y, Tong YW. Integration of high-solid digestion and gasification to dispose horticultural waste and chicken manure. Chinese J Chem Eng 2018;26:1145-51.

[9] Dussan K, Monaghan RFD. Integrated Thermal Conversion and Anaerobic Digestion for Sludge Management in Wastewater Treatment Plants. Waste and Biomass Valorization 2018;9:65-85.

[10] Wall DM, McDonagh S, Murphy JD. Cascading biomethane energy systems for sustainable green gas production in a circular economy. Bioresour Technol 2017;243:1207-15.

[11] Pecchi M, Baratieri M. Coupling anaerobic digestion with gasification, pyrolysis or hydrothermal carbonization: A review. Renew Sustain Energy Rev 2019;105:462-75.

[12] Gassner M, Maréchal F. Thermo-economic optimisation of the integration of electrolysis in synthetic natural gas production from wood. Energy 2008;33:189-98.

[13] Martínez I, Romano MC. Flexible sorption enhanced gasification (SEG) of biomass for the production of synthetic natural gas (SNG) and liquid biofuels: Process assessment of stand-alone and power-to-gas plant schemes for SNG production. Energy 2016;113:615-30.

[14] Clausen LR. Maximizing biofuel production in a thermochemical biorefinery by adding electrolytic hydrogen and by integrating torrefaction with entrained flow gasification. Energy 2015;85:94104.

[15] Pozzo M, Lanzini A, Santarelli M. Enhanced biomass-to-liquid (BTL) conversion process through high temperature co-electrolysis in a solid oxide electrolysis cell (SOEC). Fuel 2015;145:39-49.

[16] Elmegaard B, Houbak N. DNA - a general energy system simulation tool. SIMS 2005, 46th conference on simulation and modeling, Trondheim, Norway: 2005, p. 43-52.

[17] Tech. Univ. Denmark - Mech. Eng. Dep. Homepage of the thermodynamic simulation tool DNA. http://orbit.dtu.dk/query?record=231251 (accessed July 11, 2019).

[18] Nature Energy. Korskro biogas plant (in Danish). https://natureenergy.dk/anlaeg/nature-energykorskro (accessed July 11, 2019).

[19] Krich K, Augenstein D, Benemann J, Rutledge B, Salour D. Biomethane from Dairy Waste - A Sourcebook for the Production and Use of Renewable Natural Gas in California. 2005.

[20] Energy research Centre of the Netherlands. Phyllis2, database for biomass and waste. https://phyllis.nl/ (accessed July 11, 2019).

[21] Jensen AS, Larsen K. The Development of Large Pressurized Fluid Bed Steam Dryers from Fundamental Research to Industrial Plants. Dry Technol 2015;33:1631-43. 
[22] Henriksen U, Ahrenfeldt J, Jensen TK, Gøbel B, Bentzen JD, Hindsgaul C, et al. The design, construction and operation of a 75 kW two-stage gasifier. Energy 2006;31:1542-53.

[23] Ahrenfeldt J, Henriksen U, Jensen TK, Gøbel B, Wiese L, Kather A, et al. Validation of a continuous combined heat and power (CHP) operation of a two-stage biomass gasifier. Energy and Fuels 2006;20:2672-80.

[24] Bentzen J, Hummelsh $\varnothing j$ R, Henriksen U. Upscale of the two-stage gasification process. Proc of 2 world conference and technology exhibition on biomass for energy and industry., vol. 10- 14 May, 2004, p. 1004-7.

[25] Gadsbøll R $\varnothing$, Clausen LR, Thomsen TP, Ahrenfeldt J, Henriksen UB. Flexible TwoStage biomass gasifier designs for polygeneration operation. Energy 2019;166:939-50.

[26] Ahrenfeldt J, Thomsen TP, Henriksen U, Clausen LR. Biomass gasification cogeneration - A review of state of the art technology and near future perspectives. Appl Therm Eng 2013;50.

[27] Cantrell KB, Hunt PG, Uchimiya M, Novak JM, Ro KS. Impact of pyrolysis temperature and manure source on physicochemical characteristics of biochar. Bioresour Technol 2012;107:419-28.

[28] Jensen SH, Graves C, Mogensen M, Wendel C, Braun R, Hughes G, et al. Large-scale electricity storage utilizing reversible solid oxide cells combined with underground storage of $\mathrm{CO} 2$ and $\mathrm{CH} 4$. Energy Environ Sci 2015;8:2471-9.

[29] Møller HB, Lund I, Sommer SG. Solid-liquid separation of livestock slurry: Efficiency and cost. Bioresour Technol 2000;74:223-9.

[30] Wendel CH, Kazempoor P, Braun RJ. Novel electrical energy storage system based on reversible solid oxide cells: System design and operating conditions. J Power Sources 2015;276:133-44.

[31] Frandsen TQ. FarmTest - "Separering af svinegylle med GEA Westfalia UCD 305" (in Danish). 2009.

[32] Haldor Topsoe. Mehtanation catalysts from Haldor Topsoe A/S. https://www.topsoe.com/products/catalysts/pk-7r (accessed July 11, 2019).

[33] Halder Topsøe. From solid fuels to substitute natural gas (SNG) using TREMP 2009. https://docplayer.net/9077755-From-solid-fuels-to-substitute-natural-gas-sng-using-tremp.html (accessed July 11, 2019).

[34] The Danish Gas Legislation. Bekendtg ørelse om gasreglementets afsnit C-12, bestemmelser om gaskvaliteter (in danish). https://www.retsinformation.dk/Forms/R0710.aspx?id=144715 (accessed July 11, 2019).

[35] Ammongas A/S. NH3 in air and steam. http://www.ammongas.dk/nh3-in-air/ (accessed July 11, 2019). 


\section{Appendix}

\section{Detailed flowsheet of the base case system (biogas + gasifier + SOEC)}

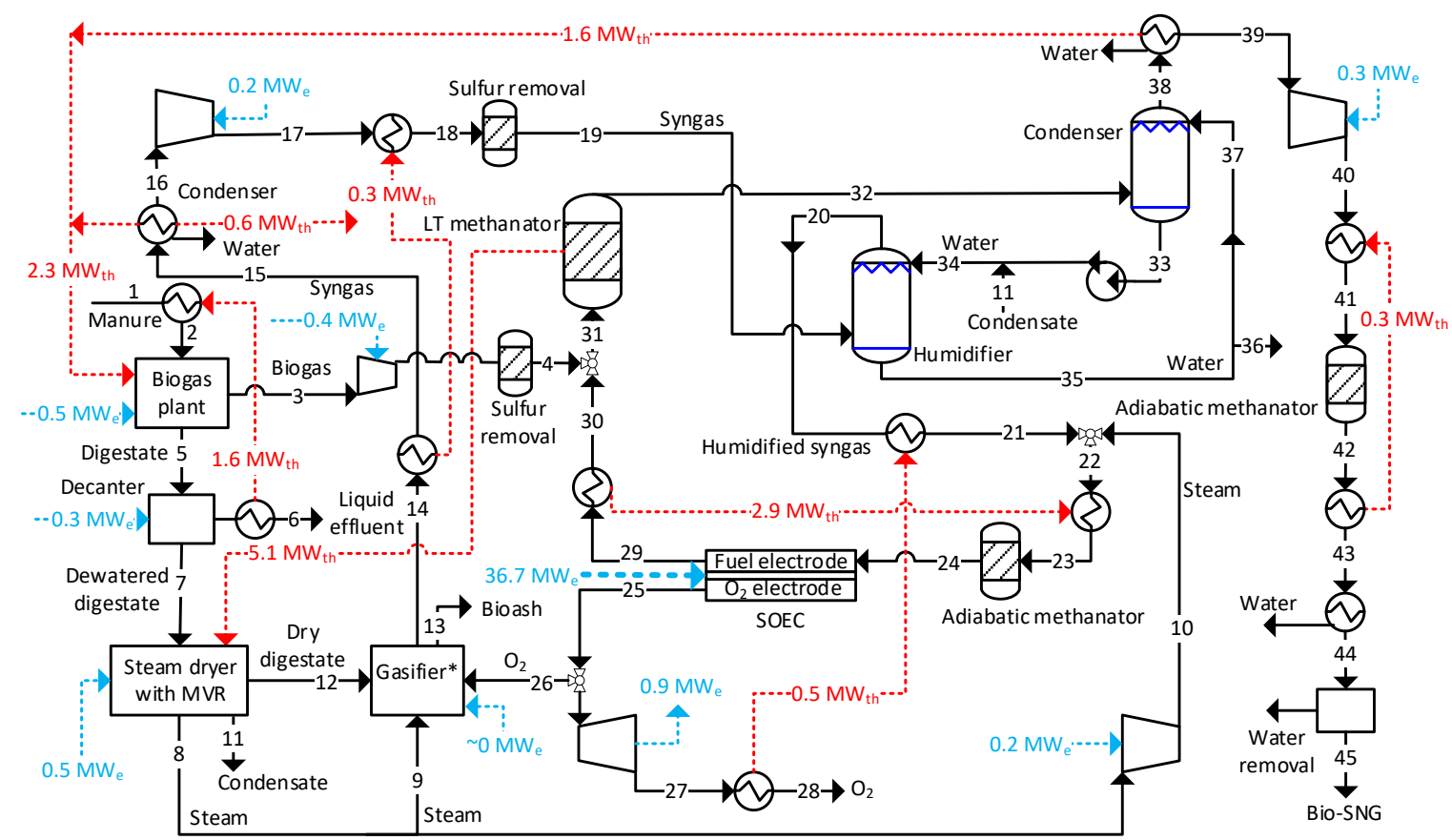

\begin{tabular}{|c|c|c|c|c|c|c|c|c|c|c|c|c|c|c|c|}
\hline & $\mathrm{t}[\mathrm{C}]$ & $\mathrm{p}$ [bar] & $\mathrm{m}[\mathrm{kg} / \mathrm{s}]$ & & $\mathrm{t}[\mathrm{C}]$ & $\mathrm{p}$ [bar] & $\mathrm{m}[\mathrm{kg} / \mathrm{s}]$ & & $\mathrm{t}[\mathrm{C}]$ & $\mathrm{p}$ [bar] & $\mathrm{m}[\mathrm{kg} / \mathrm{s}]$ & & $\mathrm{t}[\mathrm{C}]$ & $\mathrm{p}$ [bar] & $\mathrm{m}[\mathrm{kg} / \mathrm{s}]$ \\
\hline 1 & 20 & 1.00 & 34.17 & 13 & 730 & 3.56 & 0.48 & 24 & 685 & 7.05 & 3.87 & 35 & 114 & 7.05 & 21.20 \\
\hline 2 & 31 & 1.00 & 34.17 & 14 & 257 & 3.56 & 1.76 & 25 & 750 & 7.02 & 2.61 & 36 & 114 & 7.05 & 0.40 \\
\hline 3 & 37 & 1.00 & 1.48 & 15 & 157 & 3.56 & 1.76 & 26 & 750 & 7.02 & 0.32 & 37 & 114 & 7.05 & 20.80 \\
\hline 4 & 213 & 7.05 & 1.48 & 16 & 30 & 3.56 & 1.41 & 27 & 400 & 1.00 & 2.29 & 38 & 121 & 7.02 & 2.19 \\
\hline 5 & 37 & 1.00 & 32.51 & 17 & 100 & 7.05 & 1.41 & 28 & 170 & 1.00 & 2.29 & 39 & 30 & 7.02 & 1.51 \\
\hline 6 & 24 & 1.00 & 28.27 & 18 & 227 & 7.05 & 1.41 & 29 & 750 & 7.02 & 1.26 & 40 & 120 & 20.00 & 1.51 \\
\hline 7 & 37 & 1.00 & 4.24 & 19 & 227 & 7.05 & 1.41 & 30 & 262 & 7.02 & 1.26 & 41 & 200 & 20.00 & 1.51 \\
\hline 8 & 150 & 3.96 & 1.82 & 20 & 136 & 7.05 & 2.67 & 31 & 247 & 7.02 & 2.74 & 42 & 240 & 20.00 & 1.51 \\
\hline 9 & 150 & 3.96 & 0.62 & 21 & 238 & 7.05 & 2.67 & 32 & 290 & 7.02 & 2.74 & 43 & 163 & 20.00 & 1.51 \\
\hline 10 & 218 & 7.05 & 1.20 & 22 & 232 & 7.05 & 3.87 & 33 & 140 & 7.02 & 21.34 & 44 & 30 & 20.00 & 1.47 \\
\hline 11 & 178 & 9.60 & 1.12 & 23 & 596 & 7.05 & 3.87 & 34 & 141 & 7.05 & 22.46 & 45 & 30 & 20.00 & 1.46 \\
\hline 12 & 144 & 3.96 & 1.30 & & & & & & & & & & & & \\
\hline
\end{tabular}

* the gasifier flowsheet can be seen on the next figure.

Note that the electricity consumption of the steam dryer $(0.5 \mathrm{MWe})$ is used for the steam blower $(0.26 \mathrm{MWe})$ and MVR steam compressor $\left(0.24 \mathrm{MWe}\right.$ ). The temperature of the steam after MVR heating is $173^{\circ} \mathrm{C}$. MVR heating delivers $2.5 \mathrm{MW}_{\text {th }}$ of heat, which is $33 \%$ of the total dryer heat demand. 


\section{Detailed flowsheet of the gasifier on dried digested manure (biogas + gasifier + SOEC)}

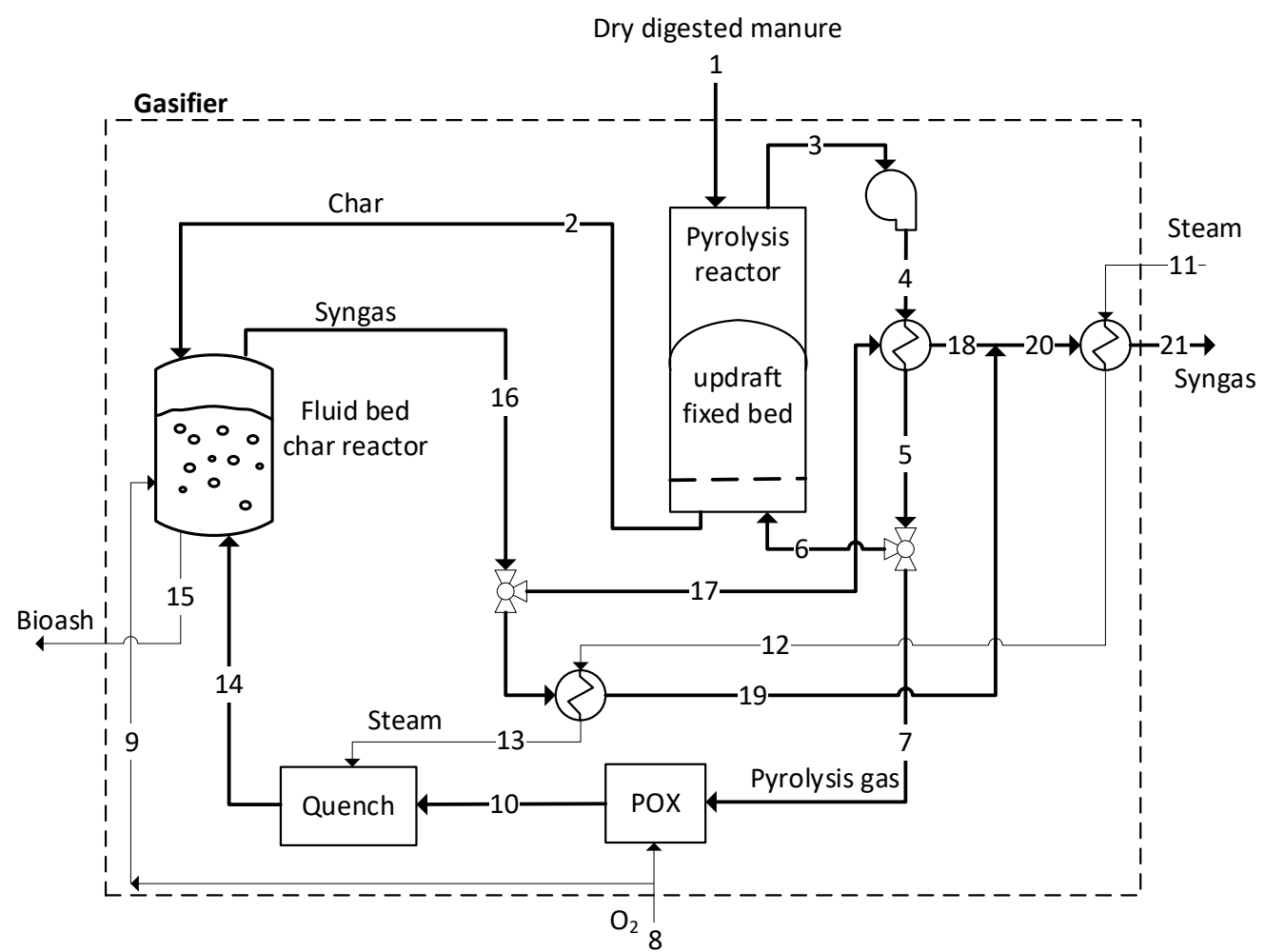

\begin{tabular}{|c|c|c|c|c|c|c|c|c|c|c|c|}
\hline & $\mathrm{t}[\mathrm{C}]$ & $\mathrm{p}$ [bar] & $\mathrm{m}[\mathrm{kg} / \mathrm{s}]$ & & $\mathrm{t}[\mathrm{C}]$ & $\mathrm{p}$ [bar] & $\mathrm{m}[\mathrm{kg} / \mathrm{s}]$ & & $\mathrm{t}[\mathrm{C}]$ & $\mathrm{p}$ [bar] & $\mathrm{m}[\mathrm{kg} / \mathrm{s}]$ \\
\hline 1 & 144 & 3.96 & 1.30 & 8 & 750 & 3.96 & 0.32 & 15 & 730 & 3.56 & 0.48 \\
\hline 2 & 670 & 3.96 & 0.65 & 9 & 750 & 3.96 & 0.01 & 16 & 730 & 3.56 & 1.76 \\
\hline 3 & 250 & 3.84 & 1.48 & 10 & 1300 & 3.96 & 0.96 & 17 & 730 & 3.56 & 1.55 \\
\hline 4 & 255 & 3.96 & 1.48 & 11 & 150 & 3.96 & 0.62 & 18 & 305 & 3.56 & 1.55 \\
\hline 5 & 680 & 3.96 & 1.48 & 12 & 275 & 3.96 & 0.62 & 19 & 305 & 3.56 & 0.21 \\
\hline 6 & 680 & 3.96 & 0.83 & 13 & 418 & 3.96 & 0.62 & 20 & 305 & 3.56 & 1.76 \\
\hline 7 & 680 & 3.96 & 0.65 & 14 & 936 & 3.96 & 1.58 & 21 & 257 & 3.56 & 1.76 \\
\hline
\end{tabular}

\begin{tabular}{|c|c|c|c|c|c|c|c|c|}
\hline & $\begin{array}{r}\text { Pyrolysis } \\
\text { gas }^{\text {a }}\end{array}$ & $\begin{array}{r}\text { Partially } \\
\text { oxidized gas }\end{array}$ & $\begin{array}{r}\text { Quenched } \\
\text { gas }\end{array}$ & Syngas & & $\begin{array}{c}\text { Digested } \\
\text { manure }\end{array}$ & Char & Bioash \\
\hline $\begin{array}{l}\text { Stream } \\
\text { number }\end{array}$ & 3 & 10 & 14 & 16 & $\begin{array}{l}\text { Stream } \\
\text { number }\end{array}$ & 1 & 2 & 15 \\
\hline $\begin{array}{l}\text { Mass flow } \\
{[\mathrm{kg} / \mathrm{s}]}\end{array}$ & 1.48 & 0.96 & 1.58 & 1.76 & $\begin{array}{l}\text { Mass flow } \\
{[\mathrm{kg} / \mathrm{s}]}\end{array}$ & 1.30 & 0.65 & 0.48 \\
\hline $\begin{array}{l}\text { Mole flow } \\
{[\mathrm{mole} / \mathrm{s}]}\end{array}$ & 46 & 55 & 90 & 103 & $\begin{array}{l}\text { Mass\% } \\
\mathrm{H}\end{array}$ & 4.5 & 0.4 & - \\
\hline Mole\% & & & & & $C$ & 35.7 & 25.4 & 4.8 \\
\hline $\mathrm{H}_{2}$ & 0.9 & 38.5 & 23.7 & 43.1 & 0 & 19.6 & 2.3 & - \\
\hline $\mathrm{CO}$ & 0.9 & 39.9 & 24.5 & 21.4 & $\mathrm{~N}$ & 3.1 & 1.5 & - \\
\hline $\mathrm{CO}_{2}$ & 35.8 & 5.2 & 3.2 & 14.1 & Ash & 35.1 & 70.4 & 95.2 \\
\hline $\mathrm{H}_{2} \mathrm{O}$ & 8.0 & 14.5 & 47.4 & 20.0 & $\mathrm{H}_{2} \mathrm{O}$ & 2.0 & - & - \\
\hline $\mathrm{CH}_{4}$ & 41.8 & $\sim 0$ & $\sim 0$ & $\sim 0$ & & & & \\
\hline $\mathrm{C}_{6} \mathrm{H}_{14}$ & 7.3 & $\sim 0$ & $\sim 0$ & $\sim 0$ & & & & \\
\hline $\mathrm{N}_{2}$ & 5.3 & 2.0 & 1.2 & 1.4 & & & & \\
\hline
\end{tabular}

\footnotetext{
a note that, as explained in the modeling section, the composition is not the actual composition, but an equivalent composition.
} 


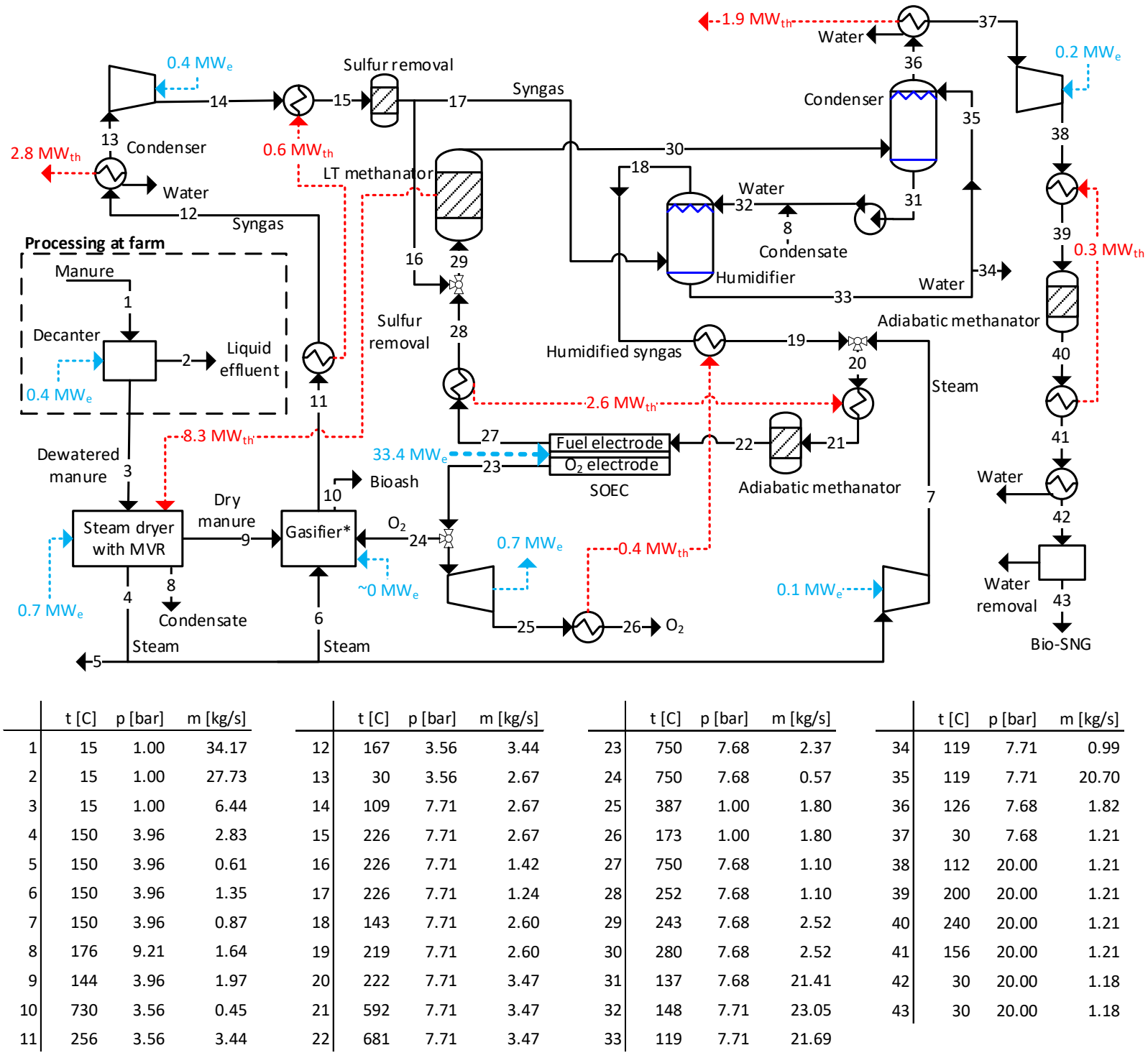

* the gasifier flowsheet can be seen on the previous figure (when operating on digestate). 
Gas compositions in the gasifier + SOEC system (stream numbers refer to the previous figure)

\begin{tabular}{|c|c|c|c|c|c|c|c|c|}
\hline & $\begin{array}{r}\text { Gasifier } \\
\text { outlet }\end{array}$ & $\begin{array}{r}\text { Humidifier } \\
\text { outlet }\end{array}$ & $\begin{array}{r}\text { Adiabatic } \\
\text { methanator } \\
\text { inlet }\end{array}$ & $\begin{array}{r}\text { SOEC } \\
\text { fuel } \\
\text { inlet }\end{array}$ & $\begin{array}{r}\text { SOEC } \\
\text { fuel } \\
\text { outlet }\end{array}$ & $\begin{array}{r}\mathrm{LT} \\
\text { methanator } \\
\text { inlet }\end{array}$ & $\begin{array}{r}\mathrm{LT} \\
\text { methanator } \\
\text { outlet }\end{array}$ & $\begin{array}{l}\text { Bio- } \\
\text { SNG }\end{array}$ \\
\hline $\begin{array}{l}\text { Stream } \\
\text { number }\end{array}$ & 11 & 18 & 21 & 22 & 27 & 29 & 30 & 43 \\
\hline $\begin{array}{l}\text { Mass flow } \\
{[\mathrm{kg} / \mathrm{s}]}\end{array}$ & 3.44 & 2.60 & 3.47 & 3.47 & 1.10 & 2.52 & 2.52 & 1.18 \\
\hline $\begin{array}{l}\text { Mole flow } \\
{[\mathrm{mole} / \mathrm{s}]}\end{array}$ & 202 & 150 & 198 & 195 & 148 & 233 & 148 & 72 \\
\hline \multicolumn{9}{|l|}{ Mole\% } \\
\hline $\mathrm{H}_{2}$ & 42.7 & 27.0 & 20.4 & 24.5 & 68.3 & 63.2 & 2.2 & 0.3 \\
\hline $\mathrm{CO}$ & 19.5 & 12.3 & 9.3 & 3.0 & 4.0 & 11.6 & $\sim 0^{\mathrm{a}}$ & $\sim 0^{\mathrm{b}}$ \\
\hline $\mathrm{CO}_{2}$ & 14.4 & 9.1 & 6.8 & 12.7 & 0.7 & 7.1 & 0.6 & $\sim 0$ \\
\hline $\mathrm{H}_{2} \mathrm{O}$ & 22.2 & 50.9 & 62.9 & 58.6 & 9.3 & 6.3 & 49.6 & $\sim 0$ \\
\hline $\mathrm{CH}_{4}$ & $\sim 0$ & $\sim 0$ & $\sim 0$ & 0.6 & 16.8 & 10.7 & 45.8 & 95.9 \\
\hline $\mathrm{N}_{2}$ & 1.3 & 0.8 & 0.6 & 0.6 & 0.8 & 1.1 & 1.8 & 3.8 \\
\hline
\end{tabular}

a ppm CO. ${ }^{\mathrm{b}} 0.8$ ppm CO. 